Chapman University

Chapman University Digital Commons

Food Science (MS) Theses

Dissertations and Theses

$5-2015$

\title{
Identification of Species in Ground Meat Products Sold on the U.S. Commercial Market Using DNA-Based Methods
}

Dawn Kane

Chapman University, dawnkane@cox.net

Follow this and additional works at: https://digitalcommons.chapman.edu/food_science_theses

Part of the Food Processing Commons, Meat Science Commons, Other Food Science Commons, and the Poultry or Avian Science Commons

\section{Recommended Citation}

Kane, D. (2015). Identification of species in ground meat products sold on the U.S. commercial market using DNA-based methods. Master's thesis, Chapman University. https://doi.org/10.36837/

chapman.000005

This Thesis is brought to you for free and open access by the Dissertations and Theses at Chapman University Digital Commons. It has been accepted for inclusion in Food Science (MS) Theses by an authorized administrator of Chapman University Digital Commons. For more information, please contact laughtin@chapman.edu. 
Identification of Species in Ground Meat Products Sold on the U.S. Commercial Market Using DNA-Based Methods

\author{
A Thesis by \\ Dawn Elizabeth Kane \\ Chapman University \\ Orange, CA \\ Schmid College of Science and Technology \\ Submitted in partial fulfillment of the requirements for the degree of \\ Master of Science in Food Science
}

May 2015

Committee in charge:

Rosalee Hellberg, Ph.D.

Lilian Were, Ph.D.

Fred Caporaso, Ph.D. 
The thesis of Dawn Elizabeth Kane is approved.

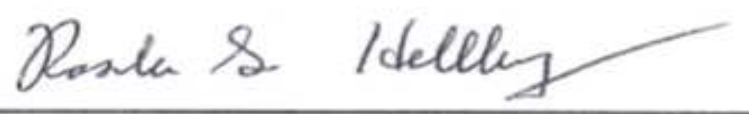

Rosalee Hellberg, Ph.D.

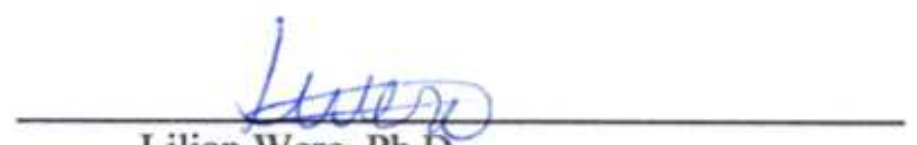

Lilian Were, Ph.D.

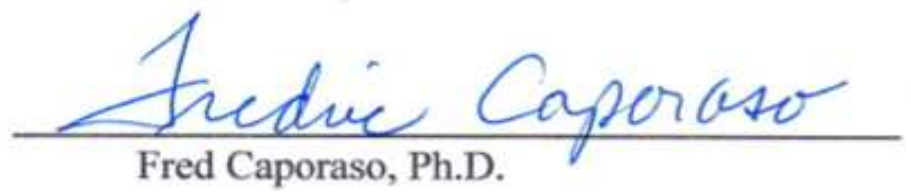

April 2015 
Identification of Species in Ground Meat Products Sold on the U.S. Commercial Market Using DNA-Based Methods

Copyright $@ 2015$

by Dawn Elizabeth Kane 


\section{DEDICATION}

This thesis is dedicated to my parents, Alan and Sharon Kane, who have stood by me and supported me through the most challenging of times. My dearest mother-in-law, Karen Rousseau who has loved and nurtured me unconditionally. My friends that have supported me through the program, especially Catherine May and Susan Lee. You are

my sisters at heart. Most importantly, with my heart and soul, to my husband, Kyle and my son, Logan. You are the air that I breathe. You both make my life complete. You are my everything. I would be lost without you. 


\section{ACKNOWLEDGMENTS}

The author wishes to thank Dr. Rosalee Hellberg for her work as thesis advisor and mentor and her never ceasing patience and support. Dr. Lilian Were for her willingness to reach students at our heart and soul as well as challenge our minds and teach us to always think critically. Dr. Fred Caporaso for his time and dedication as a committee member. Tara Okuma for her patience and equipment training. Charles Quinto for his amazing, unwavering friendship, help and support throughout this program. I have never met anyone like you. Sabrina "wifey" Davis for becoming my other half throughout this wild ride. Sophia Pollack and Amanda Shin for their incredible love, support and encouragement. Chapman University Schmid College of Science and Technology, the Office of the Chancellor and the Graduate Academic Council for funding support. 


\begin{abstract}
Identification of Species in Ground Meat Products Sold on the U.S. Commercial Market Using DNA-Based Methods
\end{abstract}

by Dawn Elizabeth Kane

Mislabeling of ground meat products is a form of food fraud that can lead to economic deception and interfere with dietary restrictions related to allergens or religious beliefs. In various parts of the world, including Ireland, Mexico and Turkey, high levels of meat mislabeling have been reported between 2000-2015. However, there is currently a lack of information regarding this practice in the United States. Therefore, the objective of this study was to test a variety of ground meat products sold on the U.S. commercial market for the presence of potential mislabeling. Forty-eight ground meat samples were purchased from online and local retail sources, including both supermarkets and specialty meat retailers. DNA was extracted from each sample in duplicate and tested using DNA barcoding of the cytochrome $c$ oxidase subunit I (COI) gene. The resulting sequences were identified at the species level using the Barcode of Life Database (BOLD). Any samples that failed DNA barcoding went through repeat extraction and sequencing. Due to the possibility of a species mixture, these samples were also tested with real-time polymerase chain reaction (PCR) targeting beef, chicken, lamb, turkey, pork and horse. Of the 48 products analyzed in this study, 10 were found to be mislabeled, with nine containing multiple meat species. Meat samples purchased from online specialty meat distributors had a higher rate of being mislabeled (35\%) compared to samples purchased from a local butcher (18\%) and samples purchased at local 
supermarkets (5.8\%). Horsemeat, which is illegal to sell on the U.S. commercial market, was detected in two of the samples acquired from online specialty meat distributors.

Overall, the mislabeling detected in this study appears to be due to reasons such as intentional mixing of lower-cost meat species into higher cost products or unintentional mixing of meat species due to cross-contamination during processing. 


\section{TABLE OF CONTENTS}

1. Introduction ............................................................................................................................. 1

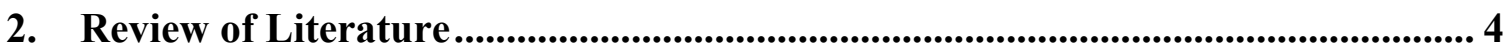

2.1. Prevalence of Mislabeled Ground Meat Globally …………………………………. 4

2.1.1. Horsemeat Traceability in Europe ……………....................................... 8

2.2. Ground Meat Regulation in the U.S........................................................... 8

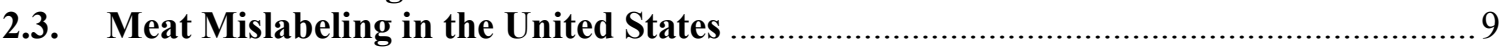

2.3.1. Horsemeat Regulations in the United States..................................................... 12

2.4. Available Methods for Species Identification ........................................................... 13

2.4.1. DNA Barcoding for use in Species Identification in Ground Meat ......................17

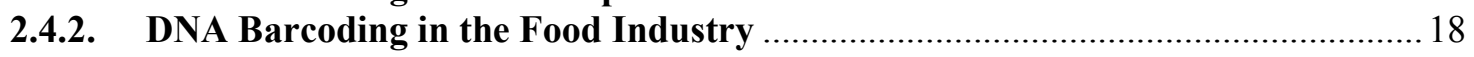

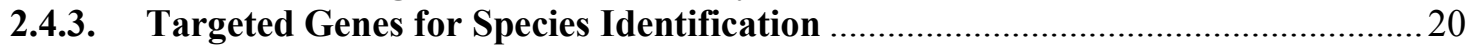

2.4.4. Shortcomings of DNA Barcoding ...................................................................2

2.4.5. Real-Time Polymerase Chain Reaction (PCR) ……………………………......2

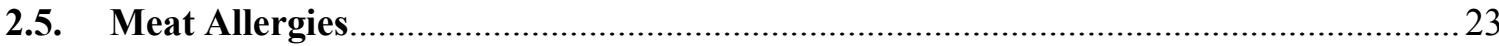

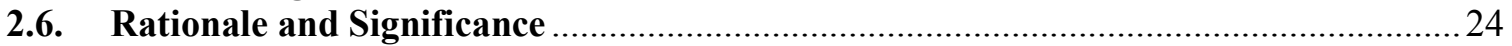

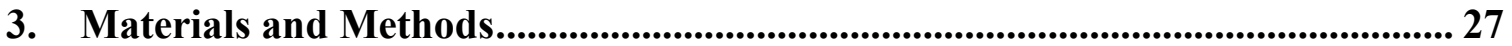

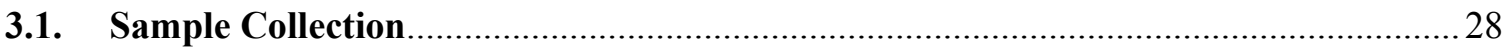

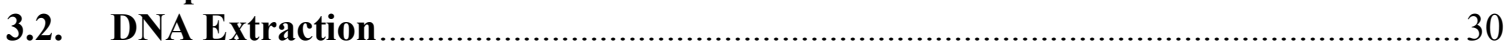

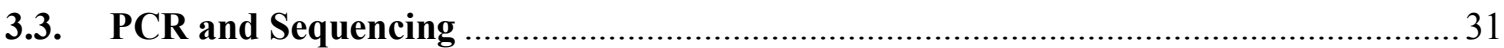

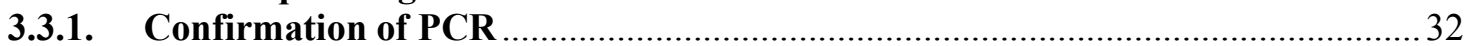

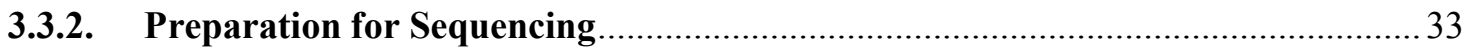

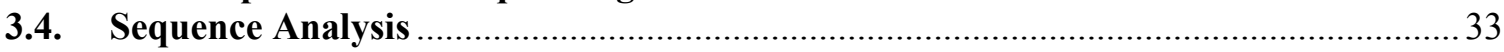

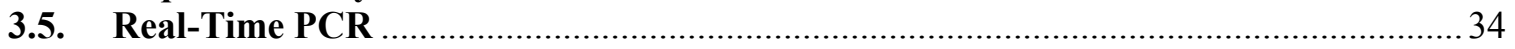

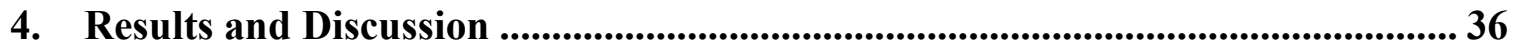

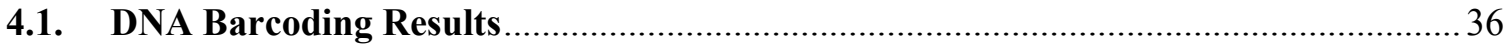

4.2. Samples Identified to Contain Mixed Species …………………………………..........

4.3. This Study as Compared to Previous Studies............................................................. 44

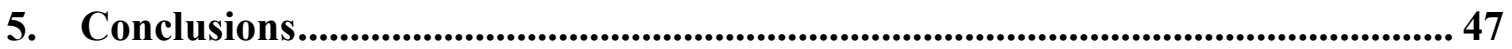

6. Recommendations for Future Studies ......................................................................... 47

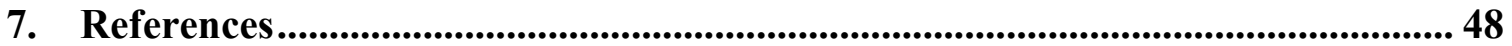

Manuscript Draft .................................................................................................................. 56 


\section{LIST OF TABLES}

Table 1: Summary of mislabeled meat products, common undeclared species, method of detection, and location of study........................................... 7

Table 2: Comparison of the various methods used to detect mislabeling in ground meat products along with their approximate time and cost per test run.................... 15

Table 3: PCR Master Mix reagent guide....................................... 32

Table 4: Real-time PCR components......................................... 35

Table 5: Real-time PCR thermocycler settings for beef, chicken, turkey, pork, lamb and

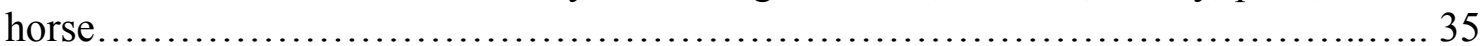

Table 6: Results for samples found to contain one species. Species were identified using the Barcode of Life Database (BOLD), except where otherwise noted.......... 37

Table 7: Combination of DNA barcoding and real-time PCR results for samples found to contain multiple species................................................... 46 


\section{LIST OF FIGURES}

Figure 1: Steps taken from DNA extraction, polymerase chain reaction (PCR) amplification, through formation of genetic 'barcode' to inputting genetic code into Barcode of Life Database (BOLD) for species identification (Logo modified from

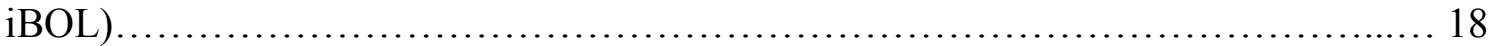

Figure 2: Diagram of sample collection through analysis of ground meat.............27

Figure 3: Summary of meat types purchased for this study, separated by retail

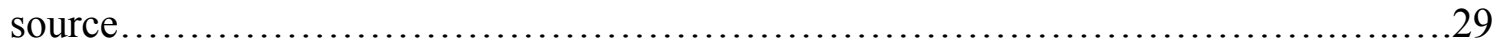




\section{LIST OF ABBREVIATIONS}

AGID - Agar-gel immunodiffusion

BLAST - Basic Local Alignment Search Tool

BOLD - Barcode of Life Database

CFR - Code of Federal Regulations

COI - Cytochrome $c$ oxidase subunit 1

ELISA - Enzyme-linked immunosorbent assay

EMA - Economically motivated adulteration

EOL - Encyclopedia of Life

FDA - Food and Drug Administration

FMIA - Federal Meat Inspection Act

FSA - Food Standards Agency

FSAI - Food Safety Authority of Ireland

GMA - Grocery Manufacturers Association

GMP - Good Manufacturing Practices

LCD - Liquid crystal display

PCR - Polymerase chain reaction

UPC - Universal Product Code

USDA, FSIS - United States Department of Agriculture, Food Safety and Inspection Service 


\section{LOGIC MODEL}

\begin{tabular}{|c|c|c|c|c|c|c|c|}
\hline \multirow[b]{2}{*}{ Situation } & \multirow[b]{2}{*}{ Priorities } & \multirow[b]{2}{*}{ Inputs } & \multicolumn{2}{|c|}{ Outputs } & \multicolumn{3}{|c|}{ Outcomes -- Impact } \\
\hline & & & Activities & Participation & Short & Medium & Long \\
\hline $\begin{array}{l}\text { Consumers rely on } \\
\text { accuracy of ground } \\
\text { meat food labeling } \\
\text { for multiple } \\
\text { reasons:Religious } \\
\text { beliefs, organic and } \\
\text { fair trade choices are } \\
\text { among some of } \\
\text { them. } \\
\text { Ground meats in } \\
\text { several countries } \\
\text { have been } \\
\text { mislabeled and } \\
\text { mixed with } \\
\text { additional species. } \\
\text { Most recent study } \\
\text { conducted and } \\
\text { reported in the U.S. } \\
\text { was in } 1994 . \\
\text { Need } \\
\text { Data collection to } \\
\text { understand the } \\
\text { prevalence of } \\
\text { ground meat } \\
\text { mislabeling in USA. }\end{array}$ & $\begin{array}{l}\text { Aseptically } \\
\text { collect } \\
\text { approximately } \\
50 \text { samples of } \\
\text { various ground } \\
\text { meat products } \\
\text { from Orange } \\
\text { County, CA } \\
\text { and online } \\
\text { retail sources. } \\
\text { Test the meat } \\
\text { products to } \\
\text { detect for } \\
\text { mislabeling. } \\
\text { Conduct } \\
\text { supplementary } \\
\text { testing for any } \\
\text { results that may } \\
\text { be ambiguous. } \\
\text { Organize and } \\
\text { publish data to } \\
\text { inform the } \\
\text { public of the } \\
\text { quality and } \\
\text { potential for } \\
\text { mislabeling of } \\
\text { ground meat. }\end{array}$ & $\begin{array}{l}\text { Advisors } \\
\text { Students } \\
\text { Knowledge } \\
\text { Time } \\
\text { Funding } \\
\text { Transporta- } \\
\text { tion } \\
\text { Testing } \\
\text { materials } \\
\text { and } \\
\text { equipment }\end{array}$ & $\begin{array}{l}\text { Design and } \\
\text { conduct } \\
\text { research, } \\
\text { including I) } \\
\text { purchasing } \\
\text { meat } \\
\text { samples, II) } \\
\text { using DNA } \\
\text { barcoding } \\
\text { methods } \\
\text { and } \\
\text { supplement } \\
\text { ary testing } \\
\text { as needed. } \\
\text { Relay } \\
\text { information } \\
\text { through, } \\
\text { final } \\
\text { defense of } \\
\text { thesis and } \\
\text { presenta- } \\
\text { tion at IFT } \\
2015 \text {. } \\
\text { Publish: } \\
\text { (Journal- } \\
\text { Food } \\
\text { Control) }\end{array}$ & $\begin{array}{l}\text { Advisors } \\
\text { Peers } \\
\text { Scientific } \\
\text { publication } \\
\text { (reviewers, } \\
\text { editors) }\end{array}$ & $\begin{array}{l}\quad \text { Knowledge } \\
\text { Understand } \\
\text { prevalence of } \\
\text { ground meat } \\
\text { mislabeling in } \\
\text { USA. } \\
\text { Identify need } \\
\text { for } \\
\text { supplementary } \\
\text { testing for any } \\
\text { results that are } \\
\text { ambiguous. } \\
\text { Identify any } \\
\text { trends in data } \\
\text { collected. }\end{array}$ & \begin{tabular}{l}
\multicolumn{1}{c}{ Actions } \\
Identify the \\
need for \\
food safety \\
and quality \\
regulations.
\end{tabular} & \begin{tabular}{l}
\multicolumn{1}{c}{ Conditions } \\
Implement \\
any food \\
safety and \\
quality \\
regulations as \\
needed. \\
Provide \\
reports on a \\
safer food \\
supply to \\
consumers \\
per FDA \\
requirements. \\
Ensuring a \\
higher quality \\
food supply.
\end{tabular} \\
\hline
\end{tabular}




\begin{tabular}{|l|l|}
\hline Assumptions & External Factors \\
\hline $\begin{array}{l}\text { Improper cleaning of equipment or lack of employee training may lead to } \\
\text { unintentional cross contamination. }\end{array}$ & $\begin{array}{l}\text { Unsanitary conditions in facilities, as well as lack of care, causing cross } \\
\text { contamination of meat species in facilities where more than one species of } \\
\text { There is a lack of data on the potential mislabeling of ground meats in the U.S. } \\
\text { As recent as 2013, countries outside the U.S., including Ireland, Mexico and } \\
\text { Turkey have been implicated in the mislabeling of ground meat products. }\end{array}$ \\
$\begin{array}{l}\text { Intentional mislabeling for economic gain. } \\
\end{array}$ \\
\hline
\end{tabular}




\section{Introduction}

Consumers rely on the accuracy of ground meat food labeling to help them make informed food choices for purchase, whether for religious purposes (Judaism and Islam do not permit the consumption of pork), organic options, or allergy concerns (Restani and others 2009; Ballin 2010). The U.S. Department of Agriculture, Food Safety and Inspection Service (USDA FSIS 2009) has regulations in place to control meat adulteration and misbranding. Although the USDA requires testing on raw and cooked ground meats for adulteration and mislabeling, the results of a 1994 Florida study discovered meat mislabeling in roughly $20 \%$ of both raw and cooked meat products collected from retail facilities, with the percent being slightly higher in the cooked meats $(22.9 \%)$ than raw $(15.9 \%)$. While both intact raw meat as well as ground meat was tested for mislabeling, only ground meat was mislabeled. Possible reasons for mislabeling of ground meat include improper cleaning of the grinding equipment in between meat species and the inability to distinguish by organoleptic means if an undeclared meat species has been mixed in or economic gain (Hsieh and others 1995; Flores-Munguia and others 2000; Everstine and others 2013; Spink and Moyer 2011). Additional studies have found the majority of meat mislabeling cases occurring in sausages, burger patties and deli meats (Cawthorn and others 2013; Flores-Munguia and others 2000). As recent as 2013, there has been an ongoing meat adulteration scandal in Europe in which undeclared horsemeat was found in products labeled as $100 \%$ beef. In the UK, lasagna products advertised as containing all beef and sold in major retail outlets as well as small convenience markets were found to contain between $60-100 \%$ undeclared horsemeat, rather than and in addition to beef (BBC News. 2013). Furthermore, in Ireland, 
authorities tested a number of beef burgers, ground beef product and salami for adulteration and found that $37 \%$ of the products tested positive for horse DNA, and $85 \%$ tested positive for pork DNA (FSAI 2013). Europe has thus become pro-active in their testing to help prevent the sale of adulterated meat products.

Assessment of proper species labeling in processed products often requires DNA or protein analysis. DNA barcoding is a molecular-based system that uses a standardized genetic region to identify biological specimens (Hebert and others 2003). The DNA barcode for most animal species is a $\sim 650$ base-pair $(\mathrm{bp})$ region of the mitochondrial gene coding for cytochrome $c$ oxidase subunit 1 (COI). This method has been found to be highly effective in identifying many animal species, as it shows relatively low genetic divergence within species and high divergence between species (Hebert and others 2003). DNA barcoding has been used to identify species in a variety of food products, including meat (D'Amato and others 2013) and seafood (Hellberg and Morrissey 2011). However, despite the advantages of DNA barcoding, it is unable to identify more than one species simultaneously. In cases such as mixed species in a ground meat product, the results would likely be a failed sequence. In these instances, additional methods such as realtime polymerase chain reaction (PCR) could be used to aid in species identification (Hellberg and Morrissey 2011).

Although extensive meat species testing has been carried out in Europe in light of the 2013 horsemeat scandal, there has been limited research carried out in the United States, with the most recent U.S. meat survey having been conducted in 1994 (Hsieh and others 1995). United States Code Title 21 Sec 676(a), state violations including the intent to defraud and distribute adulterated or mislabeled goods can be punishable as a 
misdemeanor or a felony. However, since food fraud cases are not typically health hazards, they are low on the priority list of crimes compared to food pathogens, which are responsible for approximately 76 million cases of foodborne disease each year in the United States (Reisch 2014; Spink and Moyer 2011).

The objective of this study was to test a variety of ground meat products sold on the U.S. commercial market, including domestic and exotic species, for the presence of potential mislabeling. In cases where samples failed to be identified with DNA barcoding, real-time PCR was used as a supplementary test to identify species mixtures. The hypothesis is based on the most recent meat study in the United States in 1994 (Hsieh and others 1995), that when analyzing ground meat samples for mislabeling at least $10 \%$ will be positive for mislabeling. Although USDA and FDA government agencies have updated their regulations on misbranding of meats since 1994, the increase in costs of food may lead to more fraudulent activity being committed for economic gain (USDA 2014a; USDA 2014b).

The proposed research is important, as there have been a lack of studies specifically testing ground meats for mislabeling in the United States. It is important to allow the consumer to make informed choices when purchasing meats, and the information on the label should provide them with accurate information, allowing them to make those informed choices. The expected outcome of this study is that there will be mislabeled ground meat products among the samples being tested. The ultimate goal of this research is to provide awareness into the effectiveness of government policies regarding food control and safety, and perhaps lead to the suggestion of additional measures. 


\section{Review of Literature}

\subsection{Prevalence of Mislabeled Ground Meat Globally}

In January 2013, the Food Safety Authority of Ireland (FSAI) revealed the presence of horse and pig DNA in meat products that were labeled to only contain beef. Out of 27 burgers labeled as 100\% beef, $10(37 \%)$ tested positive for horse DNA and 23 (85\%) were positive for pig DNA (FSAI 2013). Raw ingredient testing was then performed and traces of horse DNA were detected in several batches (FSAI 2013). Within a month, FSAI confirmed that beef lasagna products, claiming to be $100 \%$ ground beef, were actually positive for up to $100 \%$ horsemeat instead of the labeled beef product (FSAI 2013). This led to what had been dubbed in the UK as the "Horsegate Scandal". In light of the adulterations, testing for species misbranding became a prominent concern in Europe in assessing food quality.

Some people, depending on their religious beliefs, do not eat certain meats (Gash 2013). For example, Judaism and Islam do not permit the consumption of pork or horsemeat (Chabad.org 2014; Taylor and Willett 2013; Sistani 2013). Early Christianity bans the consumption of horsemeat, and even early Greek and Roman laws had bans on consuming horse flesh (Taylor and Willett 2013). However, in 2013, horse DNA was found in meals supplied to 68 primary schools in Lancashire, England (Jacobs 2013). Parents and school officials were under the impression that these products were $100 \%$ beef, and many of the supposed beef products were distributed to Islamic religious schools.

In 2013, in South Africa, 139 processed meats including minced meats, burger patties, deli meat and sausages were tested for mislabeling with results determining that 95 samples (68\%) were mislabeled, containing animal species not listed on the package. 
(Cawthorn and others 2013). The samples were purchased from four provinces that represent the most highly populated provinces in South Africa. Additionally, when possible, samples from high and low income regions within each province were taken to help ensure accuracy of sampling (Cawthorn and others 2013). A DNA based liquid crystal display (LCD) array was used to detect the presence of 14 different animal species, including cattle, buffalo, pig, sheep, goat, horse, donkey, rabbit, hare, chicken, turkey, goose, and two duck varieties, in food samples and the results were confirmed by PCR. The most common undeclared species was pork, then chicken. Since both pork and chicken meat typically cost less than higher priced beef, in cases of economic gain these species may have been added into a more costly product resulting in profit for the distributor. Another possible reason is that these species may be commonly ground on the same equipment shared with other species and improper cleaning techniques in between species would cause a mixing of species to occur. Sausages, burger patties and deli meats were also among the most common mislabeled meat products likely due to the difficulty to discriminate between mixed species in ground meat products by visual means alone (Cawthorn and others 2013; Angel Sentandreu and Sentandreu 2014). In 2013, in Istanbul, Ozpinar and others (2013) sampled 73 meat products including sausages, meatballs, salami and ground meat. Real-time PCR as well as DNA based LCD array showed that out of 73 samples, 39 (53.4\%) contained undeclared meat species. The products with the highest prevalence of undeclared meats were meatballs, followed by ground meat, salami and sausages. The most detected undeclared species were chicken, turkey, and sheep. No horse or pig DNA was detected in any of the samples tested. This is likely related to the fact that the Islamic religion is the primary 
religion in Istanbul, and it bans the consumption of both pork and horsemeat. A previous Turkish study published in 2006 sampled 100 various meats including fermented sausages, cooked salami, frankfurters, raw meat, meatballs, pastrami, cooked meat and canned products (Ozpinar and others 2013). Products that were labeled as only beef, including some of the meatball, sausage, frankfurter and salami types were found to contain undeclared poultry. Raw meats labeled as $100 \%$ beef were found to contain horse and deer DNA. Two major factors leading to meat mislabeling were likely economic gain, substituting lower priced poultry in place of the higher priced beef and lamb, and improper cleaning of equipment in between grinding of meat species (Ayaz and others 2006).

A study published in Mexico in 2000 sampled 40 meat products including hamburger, declared as $100 \%$ beef and traditional Mexican sausage (Flores-Munguia and others 2000). Species were detected using an agar-gel immunodiffusion (AGID) for identification of four species including beef, pork, horse and poultry. Results determined that of the 40 meat samples tested, all which were labeled as $100 \%$ product, $14(35 \%)$ tested positive for an undeclared species. Specifically, nine of the 23 hamburger samples tested positive for undeclared horse meat and five of the 17 Mexican sausage samples tested positive for horse and pork (Flores-Munguia and others 2000). A summary of the meat types, country of study, method of analyses and undeclared species reported in previous studies is found in Table $\mathbf{1}$. 
Table 1: Summary of mislabeled meat products, common undeclared species, method of detection, and location of study.

\begin{tabular}{|c|c|c|c|c|}
\hline Product & $\begin{array}{l}\text { Most } \\
\text { common } \\
\text { undeclared } \\
\text { species }\end{array}$ & $\begin{array}{l}\text { Method of } \\
\text { analyses }\end{array}$ & $\begin{array}{l}\text { Location } \\
\text { of study }\end{array}$ & Citations \\
\hline $\begin{array}{l}\text { Beef processed } \\
\text { meats }^{\text {a }}\end{array}$ & Poultry & ELISA $^{b}$ & Turkey & $\begin{array}{l}\text { Ayaz and others } \\
2006\end{array}$ \\
\hline Ground beef & Poultry & ELISA & Turkey & $\begin{array}{l}\text { Ayaz and others } \\
2006\end{array}$ \\
\hline $\begin{array}{l}\text { Beef processed } \\
\text { meats }\end{array}$ & Poultry & $\begin{array}{l}\text { DNA } \\
\text { Microarray and } \\
\text { Real time PCR }\end{array}$ & Istanbul & $\begin{array}{l}\text { Ozpinar and others } \\
2013\end{array}$ \\
\hline Meat balls & $\begin{array}{l}\text { Poultry, } \\
\text { Sheep }\end{array}$ & $\begin{array}{l}\text { DNA } \\
\text { Microarray and } \\
\text { Real time PCR }\end{array}$ & Istanbul & $\begin{array}{l}\text { Ozpinar and others } \\
2013\end{array}$ \\
\hline Ground beef & $\begin{array}{l}\text { Poultry, } \\
\text { Sheep }\end{array}$ & $\begin{array}{l}\text { DNA } \\
\text { Microarray and } \\
\text { Real time PCR }\end{array}$ & Istanbul & $\begin{array}{l}\text { Ozpinar and others } \\
2013\end{array}$ \\
\hline $\begin{array}{l}\text { Beef processed } \\
\text { meats }\end{array}$ & Pork, Sheep & $\begin{array}{l}\text { DNA LCD } \\
\text { array }\end{array}$ & $\begin{array}{l}\text { South } \\
\text { Africa }\end{array}$ & $\begin{array}{l}\text { Cawthorn and } \\
\text { others } 2013\end{array}$ \\
\hline $\begin{array}{l}\text { Lamb processed } \\
\text { meats }\end{array}$ & Pork, Beef & $\begin{array}{l}\text { DNA LCD } \\
\text { array }\end{array}$ & $\begin{array}{l}\text { South } \\
\text { Africa }\end{array}$ & $\begin{array}{l}\text { Cawthorn and } \\
\text { others } 2013\end{array}$ \\
\hline $\begin{array}{l}\text { Chicken, Beef and } \\
\text { Pork deli meats }\end{array}$ & Pork & $\begin{array}{l}\text { DNA LCD } \\
\text { array }\end{array}$ & $\begin{array}{l}\text { South } \\
\text { Africa }\end{array}$ & $\begin{array}{l}\text { Cawthorn and } \\
\text { others } 2013\end{array}$ \\
\hline $\begin{array}{l}\text { Beef or Lamb } \\
\text { patties }\end{array}$ & Chicken & $\begin{array}{l}\text { DNA LCD } \\
\text { array }\end{array}$ & $\begin{array}{l}\text { South } \\
\text { Africa }\end{array}$ & $\begin{array}{l}\text { Cawthorn and } \\
\text { others } 2013\end{array}$ \\
\hline Beef hamburger & Horse & $\mathrm{AGID}^{\mathrm{c}}$ & Mexico & $\begin{array}{l}\text { Flores-Munguia } \\
\text { and others } 2000\end{array}$ \\
\hline $\begin{array}{l}\text { Beef Mexican } \\
\text { sausage }\end{array}$ & Pork, Horse & AGID & Mexico & $\begin{array}{l}\text { Flores-Munguia } \\
\text { and others } 2000\end{array}$ \\
\hline Ground beef or veal & Sheep, Pork & $\begin{array}{l}\text { ELISA and } \\
\text { AGID }\end{array}$ & $\begin{array}{l}\text { Florida, } \\
\text { USA }\end{array}$ & $\begin{array}{l}\text { Hsieh and others } \\
1995\end{array}$ \\
\hline Ground turkey & Beef & $\begin{array}{l}\text { ELISA and } \\
\text { AGID }\end{array}$ & $\begin{array}{l}\text { Florida, } \\
\text { USA }\end{array}$ & $\begin{array}{l}\text { Hsieh and others } \\
1995\end{array}$ \\
\hline Ground lamb & Beef & $\begin{array}{l}\text { ELISA and } \\
\text { AGID }\end{array}$ & $\begin{array}{l}\text { Florida, } \\
\text { USA }\end{array}$ & $\begin{array}{l}\text { Hsieh and others } \\
1995\end{array}$ \\
\hline
\end{tabular}




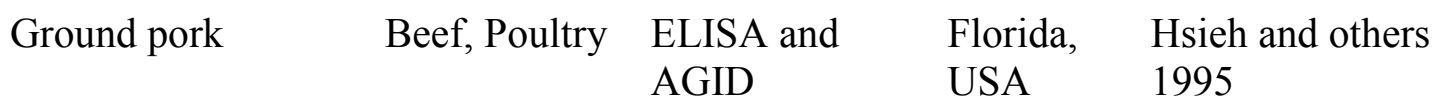

${ }^{\text {a }}$ Processed meats include salami, frankfurters and sausages

${ }^{\mathrm{b}}$ Enzyme-linked immunosorbent assay

${ }^{c}$ Agar-gel immunodiffusion

\subsubsection{Horsemeat Traceability in Europe}

In Europe, horsemeat is consumed mainly in Italy, France, Belgium and Holland (Marlin and others 2011). While it is legally consumed, the concern is proper labeling. Sarpong (2014) notes that the concern with the EU is their traceability. When conducting routine supply chain exercises, products and handlers have failed, which may be indicative of how real products in production will fare. EU officials suggest adding additional safety experts to their production lines and food traceability teams. The concept behind this is that providing additional experts to these teams would allow greater knowledge and help keep the production line more accountable as well as improve the quality of the food products (Sarpong 2014; Everstine 2013). Ideally, this collaboration will help supply chain managers trace orgin, transit and destination of meat products, leading to greater success of traceability of products through the supply chain and to the consumer.

\subsection{Ground Meat Regulation in the U.S.}

Laws in the United States regarding mislabeling involve several agencies: USDA and FDA. Title 9 of the United States government Code of Federal Regulations (CFR) Part 301.2 has several definitions of the term "misbranded", including the following: "This term applies to any carcass, part thereof, meat or meat food product under one or 
more of the following circumstances: (1) If its labeling is false or misleading in any particular way; (2) If it is offered for sale under the name of another food"(CFR 2000).

The USDA Meat Inspection Act, under 21 CFR 12, Inspection requirements; Adulteration and Misbranding is specific to domestic meat or meat products of any animals for human consumption including cattle, sheep, swine and goats, and states that they shall not be adulterated or misbranded at the time of sale, while they are being transported in commerce, or held for sale after transportation (CFR 2009). In addition, the USDA also monitors game meats that are farm raised or produced in the United States. According to USDA, game meats refer to wild animals or birds that may be legally hunted and consumed (USDA 2011). In contrast to the USDA, the FDA monitors imported game meats as stated in Federal Food Drug and Cosmetic Act (FD\&C), Chapter VIII, Section 381(m) (FDA 2006). While ground meat products have not been assessed for mislabeling in the United States in over 20 years, mislabeling is a frequently occurring situation in the seafood industry. A study conducted in 2014 by the conservation group, Oceana, found that approximately $33 \%$ of fresh seafood samples purchased in the USA were not what they claimed to be (Reisch 2014). For example, every snapper sample tested in Seattle was incorrectly labeled, and nationwide, $84 \%$ of samples labeled as tuna were actually escolar (Reisch 2014). These tests used DNA barcoding methods for species identification. Reisch (2014) notes that food fraud still is not considered a high priority crime in the USA.

\subsection{Meat Mislabeling in the United States}

While so much testing for undeclared meat species has gone on around the world, it would seem that the United States would follow suit and test for mislabeling as well 
since food fraud in the U.S. is already known to be a multi billion dollar concern. However USDA FSIS regulations only require testing for pathogens prior to meat leaving the processing plant (USDA FSIS 2013). While the United States does have regulations in place indicating that misbranding of meat can be a crime upwards of a felony, it has not made the crime of food fraud a high priority. Part of the reason for this is that the cost involved in seizing fraudulent food products just does not compare to fraudulent products. In 2013, U.S. Customs \& Border Protection seized \$200,000 of fraudulent food, compared with $\$ 700$ million of fake handbags and wallets (Spink and Moyer 2011). Even European regulators have been more actively prosecuting meat cases that test positive for harmful pathogens affecting food safety, compared with issues of food quality, which have not held the same priority. However, according to European officials, as of 2014, food crimes in the UK are now being made a priority following the horsemeat scandal of 2013 (Lawrence 2014).

The most recent study conducted in the U.S. was published in 1995 and took place in Florida (Hsieh and others 1995). The researchers sampled a total of 902 meats: 806 raw, and 96 cooked, purchased from various retail suppliers. Both enzyme linked immunosorbent assay (ELISA) and agar-gel immunodiffusion (AGID) testing were used for species identification. The ELISA test, a qualitative test, was used to identify lamb and poultry species in raw meat samples and all undeclared species in the cooked or cured samples, while AGID was used in identification of beef, pork and horse species in raw meats. The results indicated that in all raw and cooked meat samples combined, over $20 \%$ of samples had undeclared species (Hsieh and others 1995). Of these, $15.9 \%$ of the raw meats and $22.9 \%$ of the cooked meats were mislabeled. In beef and veal, the primary 
undeclared species was sheep, while in pork products, turkey and poultry were the primary undeclared species, which can be assumed to be for reasons of economic gain. Substitution of lower cost sheep into the higher priced veal would allow the distributor to sell the products labeled as veal while making more of a profit. However, instances in which beef was the primary undeclared species in pork and poultry products were most likely due to unsanitary practices, primarily being improper cleaning of grinding equipment between meat species, resulting in cross contamination leading to no monetary gain (Hsieh and others 1995; Everstine and others 2013). All of the samples were also tested for horsemeat, however no horsemeat was detected, nor should any be in ground meat samples in the United States. In 2007, Congress passed the American Horse Slaughter Prevention Act, prohibiting the sale of equines including horses and mules for human consumption under the Federal Meat Inspection Act (FMIA).

The results of the Florida study discussed above revealed that ground veal products had violation rates that were approximately three times higher than those of ground beef to have an undeclared species present, due to the fact that ground veal products are sold at a higher price than ground beef (Hsieh and others 1995). This type of substitution is referred to as economically motivated adulteration (EMA) (Everstine and others 2013). EMA is a challenge to the food industry, as these acts are designed to evade detection. While large scale acts such as the horsemeat scandal in Europe have been identified, many small scale frauds that may include mixing in expired meat with fresh meat or extending expiration dates, have gone undetected (Everstine and others 2013; NSF 2014). 
Laws in the United States regarding mislabeling involve several agencies: USDA and FDA. The 21 CFR 12; Inspection requirements; Adulteration and Misbranding law is specific to domestic meat or meat products of any animals for human consumption including cattle, sheep, swine and goats, and states that they shall not be adulterated or misbranded at the time of sale, while they are being transported in commerce, or held for sale after transportation (CFR 2009). In addition, the USDA also monitors game meats that are farm raised or produced in the United States. According to USDA (USDA 2011), game meats refer to wild animals or birds that may be legally hunted and consumed. In contrast to the USDA, the FDA monitors imported game meats as stated in Federal Food Drug and Cosmetic Act (FD\&C), Chapter VIII, Section 381(m) (FDA 2006). 9 CFR 301.2 defines misbranding as if its label is false or misleading in any way, or if a meat product is offered for sale under the name of another food (CFR 2000).

\subsubsection{Horsemeat Regulations in the United States}

In 2007, nine years after voters first passed California Proposition 6, which banned the slaughter of horses and similar equines for sale for their meat for human consumption, Congress passed the American Horse Slaughter Prevention Act, prohibiting the sale of equines including horses and mules for human consumption under the Federal Meat Inspection Act (FMIA) (Potter 2012; Library of Congress 2011). Since its inception, there have been many amendments to the Act, with the most recent being in 2011. The Act includes laws regarding the prohibition of shipping, transporting, moving, delivering, receiving, possessing, purchasing, selling or donation of horses and other equines for human consumption (Library of Congress 2011). Along with a nationwide ban on selling horsemeat for human consumption, some states, like California have a law 
of repugnance. In 1998, section 598 of the California Penal Code put into effect the law that horsemeat may not be offered for sale for human consumption. No public eating place may offer horsemeat for human consumption (Roth 2007). Neither of these laws prohibits the slaughter of horses, it is only illegal for human consumption. After slaughter, typically horses are sent to rendering plants where the horse components can be used to produce various items such as tallow, horsehair and glue (Smiley 2008). These laws are written carefully and specifically, but loopholes have been found enabling the United States to raise and then ship the horses to other countries, such as Mexico and Canada to be slaughtered (Cawthorn and Hoffman 2013; Potter 2012). In 2010, beef imports from Mexico to the United States roughly totaled 107 million pounds. This beef is primarily mixed with trim and ground to create processed beef products (Johnson and Hagerman 2012). While there are labeling requirements for the meat being shipped, there are few inspections that occur, leaving the possibility of horsemeat to contaminate beef products (Johnson and Hagerman 2012; USDA. 2015).

\subsection{Available Methods for Species Identification}

A comparison of methods used for species identification analyses, time per test, and estimated cost per test is summarized in Table 2. When comparing these tests, PCR based tests have been considered an industry standard for identification of animal species. DNA barcoding is utilized after PCR has been performed. The DNA code retrieved from the $\mathrm{COI}$ region is entered into the BOLD library to be matched to an existing sequence. Both ELISA and AGID are protein rather than DNA based tests, which means that more tissue may be needed to get an adequate sample for accurate analysis (Yosef and others 2014). In addition, these tests do not have the same sensitivity as DNA based tests. For 
example, in some ELISA tests, the lowest detection of a species may be $2-10 \%$ compared to PCR which has a detection level of $0.1 \%$ (Cawthorn and others 2013; Ozpinar and others 2013; Hsieh and others 1995). Liquid crystal display (LCD), or DNA microarray testing has a high sensitivity of $\sim 0.1 \%$, however the test can pick up high levels of background resulting in false positives (McLoughlin 2011; Yosef and others 2014). 
Table 2: Comparison of the various methods used to detect mislabeling in ground meat products along with their approximate time and cost per test run.

\begin{tabular}{|c|c|c|c|c|}
\hline $\begin{array}{l}\text { Method of } \\
\text { analysis }\end{array}$ & $\begin{array}{c}\text { Estimated cost } \\
\text { per test }\end{array}$ & $\begin{array}{l}\text { Time per test } \\
\text { run }\end{array}$ & Pros and cons & References \\
\hline ELISA $^{\mathrm{a}}$ & $\begin{array}{l}\text { Varies with tests } \\
\text { run, but } \$ 3.90 \\
\text { average }\end{array}$ & $\sim 2 \mathrm{~h}$ & $\begin{array}{l}\text { Pro: Rapid, time efficient, effective for } \\
\text { identification of both raw and cooked } \\
\text { meats } \\
\text { Con: Lowest species detection level in a } \\
\text { mixed meat sample is } 2-10 \% \text {. False } \\
\text { results may occur due to any } \\
\text { contamination }\end{array}$ & $\begin{array}{l}\text { Hsieh and } \\
\text { others } 1995, \\
\text { Ayaz and } \\
\text { others } 2006, \\
\text { elisa-tek.com }\end{array}$ \\
\hline $\mathrm{AGID}^{\mathrm{b}}$ & $\begin{array}{l}\text { Varies with tests } \\
\text { run, but } \$ 1.33 \\
\text { average }\end{array}$ & minimum $24 \mathrm{~h}$ & $\begin{array}{l}\text { Pro: Easy to perform. Considered } \\
\text { relatively economical Con: Variable } \\
\text { sensitivity levels e.g.: cannot detect sheep } \\
\text { and turkey accurately. False results may } \\
\text { occur due to any contamination }\end{array}$ & $\begin{array}{l}\text { Hsieh and } \\
\text { others } \\
\text { 1995,Flores- } \\
\text { Munguia and } \\
\text { others 2000, } \\
\text { vmrd.com }\end{array}$ \\
\hline $\begin{array}{l}\text { DNA } \\
\text { Barcoding }\end{array}$ & $\begin{array}{l}\$ 2.00 \text { per } \\
\text { sequence } \\
\text { analysis }\end{array}$ & $24-48 \mathrm{~h}$ & $\begin{array}{l}\text { Pro: Selection of a universally present } \\
\text { gene region allows for use of universal } \\
\text { primers for ease of DNA identification. } \\
\text { Low divergence }(<2 \%) \text { within a species. } \\
\text { Con: Species must already be in BOLD } \\
\text { library }\end{array}$ & $\begin{array}{l}\text { Hebert and } \\
\text { others 2003, } \\
\text { genscript.com } \\
\text { CBOL } 2010\end{array}$ \\
\hline $\begin{array}{l}\text { Species- } \\
\text { specific } \text { PCR }^{\mathrm{c}}\end{array}$ & $\$ 1.80$ & $\sim 2.5 \mathrm{~h}$ & $\begin{array}{l}\text { Pro: Able to use multiple species primers. } \\
\text { Highly specific for species identification, } \\
0.1 \% \text { accuracy. Con: False positive may } \\
\text { occur due to any contamination }\end{array}$ & $\begin{array}{l}\text { Cawthorn and } \\
\text { others } 2013 \text {, } \\
\text { sigmaaldrich. } \\
\text { com }\end{array}$ \\
\hline
\end{tabular}




$\begin{array}{lll}\begin{array}{l}\text { Real-time } \\ \text { PCR }\end{array} & \$ 2.20 & \sim 1.5-2 \mathrm{~h} \\ & & \\ & & \sim 45 \text { min } \\ \text { LCD } & \\ & \$ 3.00 & \text { (excluding } \\ \text { PCR time) }\end{array}$

Pro: Faster than PCR. Favors automation, species detection to $0.1 \%$ accuracy Con: Must amplify each DNA type separately. More costly than other methods

Pro: Can detect more than one species in a reaction. Easy sample preparation. High sensitivity of $0.1 \%$ Con: Not quantitative. High background, resulting in improper reads
Ozpinar and others 2013, Mackay and others 2002 qiagen.com Yosef and others 2014, Cawthorn and others 2013, McLoughlin 2011

${ }^{a}$ Enzyme-linked immunosorbent assay, ${ }^{b}$ Agar-gel immunodiffusion

${ }^{\mathrm{c}}$ Polymerase chain reaction, ${ }^{\mathrm{d}}$ Liquid crystal display 


\subsubsection{DNA Barcoding for use in Species Identification in Ground Meat}

The name, or descriptor of a DNA barcode allows for association between retail universal product code (UPC) barcodes that may be used in stores and the genetic 'barcode' created by Paul Hebert (iBOL 2014). In both cases, they provide a scannable, yet unique identifier for the product in question (Mitchell 2008). Hebert and others (2003) proposed a new system of species identification using a $\sim 650$ base pair (bp) region from a standardized genetic section, specifically the mitochondrial gene coding for cytochrome $c$ oxidase subunit 1 (COI). DNA is extracted from a sample, and amplified through polymerase chain reaction (PCR) to produce millions of copies of the DNA barcode. Once the DNA barcode has been sequenced, species identities can be queried against the Barcode of Life Database (BOLD) (Figure 1). BOLD is a public online reference library that can assign identities to unknown specimens (iBOL 2014). DNA species and taxonomic information is provided when a positive match is made. The BOLD library currently has over two million sequences, and almost two hundred thousand unique species (iBOL 2014). If a species is unable to be identified using BOLD, a search is conducted in GenBank using the Basic Local Alignment Search Tool (BLAST). Between the two databases, there is a high certainty of finding a species match. 


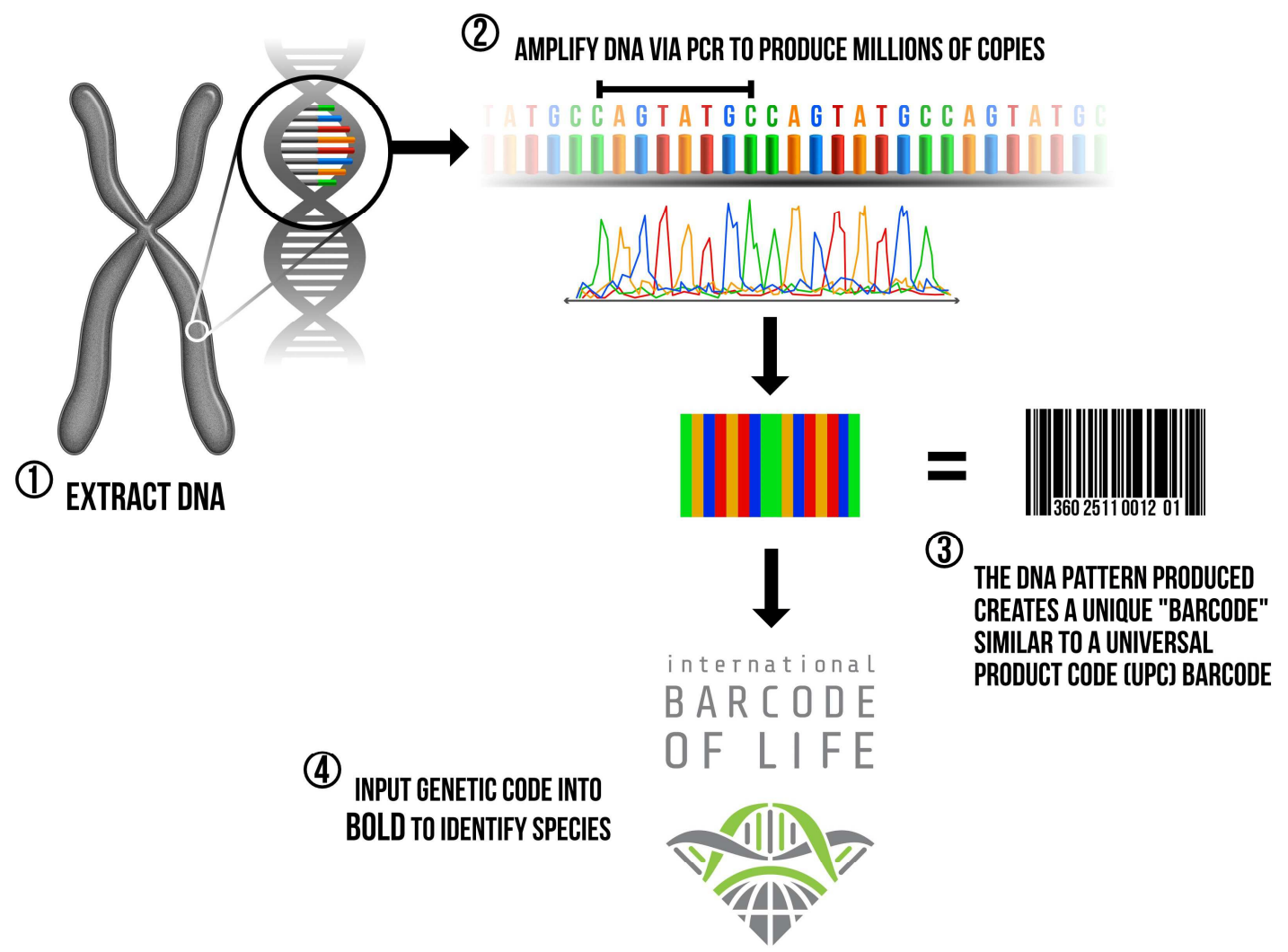

Figure 1: Steps taken from DNA extraction, polymerase chain reaction (PCR) amplification, through formation of genetic 'barcode' to inputting genetic code into Barcode of Life Database (BOLD) for species identification (Logo modified from iBOL).

\subsubsection{DNA Barcoding in the Food Industry}

In 2011, studies focusing on seafood fraud in North America and Europe found that mislabeling occurred in 15-43\% of all commercial seafoods (Hellberg and Morrissey 2011; Galimberti and others 2013). The use of DNA barcoding for the identification and traceability in the seafood industry has been successful because there are a higher number of seafood species, compared to mammalian specie, making the BOLD library more effective for identification of fish and seafoods than mammalian products (Galimberti and others 2013). The more species the database has in place, the easier it is to identify a 
specimen. The quandary lies when the BOLD library does not have a specific specimen and then the user is redirected to a different database, typically, GenBank's Basic Local Alignment Search Tool (BLAST).

Verification of food authenticity is primarily reliant on the analysis of proteins and/or DNA sequences. However, it has been argued that DNA based methods are more effective than protein based methods. DNA is more thermostable than proteins in consumable meat, such as beef, deer, pig, chicken, sheep, goat and rabbit (Lockley and Bardsley 2000), so the composition of DNA is less likely to be degraded by the processing of foods compared to proteins which can be denatured with heat and processing. Furthermore, the majority of commercial protein based tests, such as ELISA and AGID have been designed to detect plasma proteins, however, because of crossreations between protein and other bacteria, false positives are common (Lockley and Bardsley 2000). Since DNA is present in all cells, DNA barcoding can be applied to a wider variety of food products than protein analysis alone, and has the potential to simplify methods without risking precision (Galimberti and others 2013; Lockley and Bardsley 2000). However, many meat species are still being authenticated by protein based techniques, since DNA barcoding is considered a new development. As the BOLD library continues to grow with more species identifiers added to it, DNA barcoding may be more successful in identifying illegal sales of threatened and endangered meat species, or uncovering commercial companies selling inaccurately labeled meat product. DNA barcoding could also be used as a laboratory validation tool, to ensure that species are what they are intended to be (Mitchell 2008). 


\subsubsection{Targeted Genes for Species Identification}

For BOLD to be successful, an ideal barcoding gene needs to be identified (Stoeckle 2003). The ability to standardize a particular gene region present in most of the animal population allows for the system to become universal (Mitchell 2008; Ratnasingham and Hebert 2013). The gene should be present in all forms of life, yet contain enough variation to easily identify multiple species. Amplification using a broad range of primers allows for amplification of an unknown specimen. Furthermore, the gene should have the ability to identify the species using a short target sequence that would allow for amplification of sub-par or damaged specimens, as well as reducing sequencing costs, since a smaller amount is needed (Stoeckle 2003). The mitochondrial gene, COI was identified as being successful on all these levels (Stoeckle 2003).

The COI has an important advantage, in that it has very robust universal primers, allowing for recovery of barcodes from most animal species (Hebert and others 2003; Stoeckle 2003). In addition the COI gene also has the ability to differentiate within species as well as between different species quite sensitively (Hebert and others 2003; Stoeckle 2003) and allowed for species identification in 95\% of animal species examined (Ratnasingham and Hebert 2013). The main protein coding genes used in animal species identification are COI and cytochrome $b(c y t b)$, which are both present in all eukaryotes (Stoeckle 2003). While both have been used in analysis of organisms, the COI gene was able to provide better insight into the evolutionary relationships within a species (Hebert and others 2003; Stoeckle 2003). Although the $c y t b$ gene was found to have a larger divergence between similar species, the observed divergence percentage was only based upon the vertebrae class (Johns and Avise 1998). Therefore, COI was the gene of choice 
when building the BOLD system. Species can be identified with $98-100 \%$ accuracy using the COI gene and the BOLD combination (Galimberti and others 2013; Stoeckle 2003; Johns and Avise 1998). However, Stoeckle (2003) states that ultimately, the choice between COI and cytb is also partially arbitrary, with the overall differences being minimal.

\subsubsection{Shortcomings of DNA Barcoding}

The purpose of DNA barcoding is to identify an unknown sample of a known species (Piotrowska 2009). Since BOLD acts as a library, the sequenced DNA barcode must already be in existence within that library to be identified (Hebert and others 2003). There is not always adequate species identification information available which can be due to reasons such as inconsistent mutation rates, interbreeding and domestication, and reduced effective population size, among others. Mitochondrial DNA (mtDNA) is maternally inherited (Ballin 2010; Bremer and others 1996), thus making it an unsuccessful choice when identifying hybrid species. Two species that have interbred may have such similar COI regions that they are unable to be accurately identified. For example, guanaco, llama, and alpaca likely cannot be differentiated using the COI barcode region due to a history of interbreeding and domestication (Barreta and others 2013). Initial studies stated that the unique barcode region in all organisms was found in the COI gene region (Lockley and Bardsley 2000). However, further research has shown that there are some species of plants, sea anemones, corals, amphibians and jellyfish that do not have unique identifying sequences at the COI location (Piotrowska 2009). In addition, Hellberg and Morrissey (2011) state that despite the advantages of DNA barcoding, it is unable to identify multiple species in the same product. For example, as in 
ground meat products that contain mixed species. In these cases, alternative methods such as real-time PCR must be employed.

\subsubsection{Real-Time Polymerase Chain Reaction (PCR)}

Real-time polymerase chain reaction (PCR) is a DNA based identification method that is able, through use of species-specific primers, to identify multiple species in mixed meat products (Okuma and Hellberg 2014). One method of real-time PCR includes DNA-binding fluorophores. In this method, double-stranded DNA binds to a fluorogenic molecule. When exposed to the required wavelength of light, the molecule will fluoresce for easy readability, indicating a positive result (Mackay and others 2002). For this study, SYBR ${ }^{\circledR}$ Green SuperMix (Bio-Rad, Hercules, CA) was used as the fluorescent dye. When $\mathrm{SYBR}^{\circledR}$ Green is used, both a Cycle threshold $(\mathrm{Ct})$ and melting curve need to be generated to achieve a positive qualitative result. Cycle threshold is the state in the PCR cycle in which the gain in fluorescence generated by the specific amplicon being read exceeds the baseline fluorescence (Mackay and others 2002). The melting curve signifies the point at which at least half of the strands of DNA bound to the dye have annealed, leaving only single strands of DNA. Fluorescent dyes also have the ability to bind to primer-dimers, therefore the notation of the temperature of the melt curve ensures that the dye did bind to DNA, and that the DNA was denatured at the appropriate temperature (Safdar and Junejo 2015; Mackay and others 2002). The melt curve is indicative that the appropriate temperatures were used/reached during the protocol (Safdar and Junejo 2015). Real-time PCR and melt curve analysis has had successful use in species determination of ground meat products (Ballin and others 2009). 


\subsection{Meat Allergies}

An allergy to meat is rare, and is more commonly seen in children than adults (Restani and others 2009). Typically, a child will outgrow a meat allergy as they transition through the first years of life (Restani and others 2009). An allergy is formed in the body by Immunoglobulin E (IgE), an antibody that binds to allergens and triggers the release of substances from cells that can cause inflammation (ACAAI. 2014). The level of inflammation can vary from mild, including skin rash and asthma, to fatal anaphylaxis. In the case of meat allergies, there appears to be two distinct causes. The first being that an individual is allergic to the specific carbohydrate galactose- $\alpha-1,3-$ galactose $(\alpha$-gal) in meat. Typically this is classified into categories. A person who is allergic to beef will tend to have similar reactions to other mammalian meats, such as lamb and pork, (and will need to remove them from their diet), but not necessarily avians. In contrast, those who are allergic to avian meat may be totally unreactive to mammalian meats (Restani and others 2009). In both cases, reactions tend to develop over the course of 3-6 h, however the reason for this delayed onset is still being researched. The second onset of a meat allergy is believed to be from a bite from the Lone Star tick. This tick can cause people to develop an allergy, again to $\alpha$-gal, specifically in red meat. Because this tick can cause people to develop a meat allergy later in life, there is no conclusive data as to how much of the population is actually allergic to meat, but it is reported to occur in approximately $3 \%$ of all adult allergy cases and 3-15\% of all pediatric allergy cases (ACAAI. 2014).

The concern of cross contamination, or mislabeling in meat products is dangerous for people who have a meat allergy. If avian meat is cross-contaminated with 
mammalian meat, this could lead to a potentially fatal episode in someone who has the allergy. However, no data has been published to date determining the lowest levels of reactivity.

\subsection{Rationale and Significance}

Consumers want to know that the product they are purchasing is accurately labeled (Ballin and others 2009). Religions such as Judaism and Islam do not permit the consumption of pork, and when purchasing a product that is declared to be $100 \%$ beef, consumers expect that product to be accurate and not contain unlabeled pork (Ballin and others 2009; Hsieh and others 1995). Once ground meat products are deboned and ground up, they do not provide any distinguishing identities to help assess if species have been mixed together (Flores-Munguia and others 2000; Handy and others 2011b; Angel Sentandreu and Sentandreu 2014). This is the reason why DNA based methods, such as DNA barcoding and PCR, are being employed for detection of undeclared species.

Ground meat product mislabeling has occurred globally. Within the last 10 years (2003-2014), countries including Ireland, Mexico and Turkey have been more stringent about testing their products for undeclared species (Cawthorn and others 2013; FloresMunguia and others 2000; Ozpinar and others 2013). The United States, however, has been lacking in testing of ground meat mislabeling, due to food fraud not being a priority in the United States (Spink and Moyer 2011; Reisch 2014). The focus is on safety and because of the complex nature of supply chains, it is unlikely that those who commit fraud will be punished (Lawrence 2014). This may be a reason why the most recent ground meat study was conducted over 20 years ago (Hsieh and others 1995). 
The rationale behind this study is to examine ground meat mislabeling in a set of products purchased from various retailers in the United States, since the most recent study published for ground meat mislabeling in the United States is over 20 years old.

The overall goal is to test a variety of ground meat samples purchased from retailers in the United States for potential mislabeling. The overall goal is to be accomplished via the following specific objectives:

I. Extract DNA from $\sim 50$ samples of ground meat purchased from various retail establishments in the United States and utilize DNA barcoding to assess for potential mislabeling. The working hypothesis is that, per the most recent study in the United States, at least $10 \%$ of ground meat samples will be found to be potentially mislabeled (Hsieh and others 1995).

II. Utilize supplementary testing such as real-time PCR for any samples that fail DNA barcoding, to attempt to assess what specific undeclared species may be present. The working hypothesis for this aim is that ground meat samples containing species mixtures will fail assembly using DNA barcoding, and that real-time PCR will allow for the discovery of specific undeclared species present in the sample(s).

The significance of this study is to understand the need for food quality monitoring within meat processing plants in the United States and from government regulatory agencies such as the USDA. Once meat products arrive at the retail level, they are usually already packaged indicating that mislabeling or cross-contamination would occur at the processing stage. The results are significant in light of the 2013 European "Horsegate scandal" and prevalence of mislabeling globally, an assessment of the 
potential mislabeling in the United States is considerably overdue. The expected outcome is to provide a greater awareness to the general population of potential mislabeling that occurs in ground meat products, for reasons such as economic gain or unsanitary conditions. This research could benefit consumers and the meat industry by identifying weaknesses in the quality control of the United States ground meat products. This would help the meat industry to address potentially fraudulent activity and/or improve cleaning practices within processing plants. 


\section{Materials and Methods}

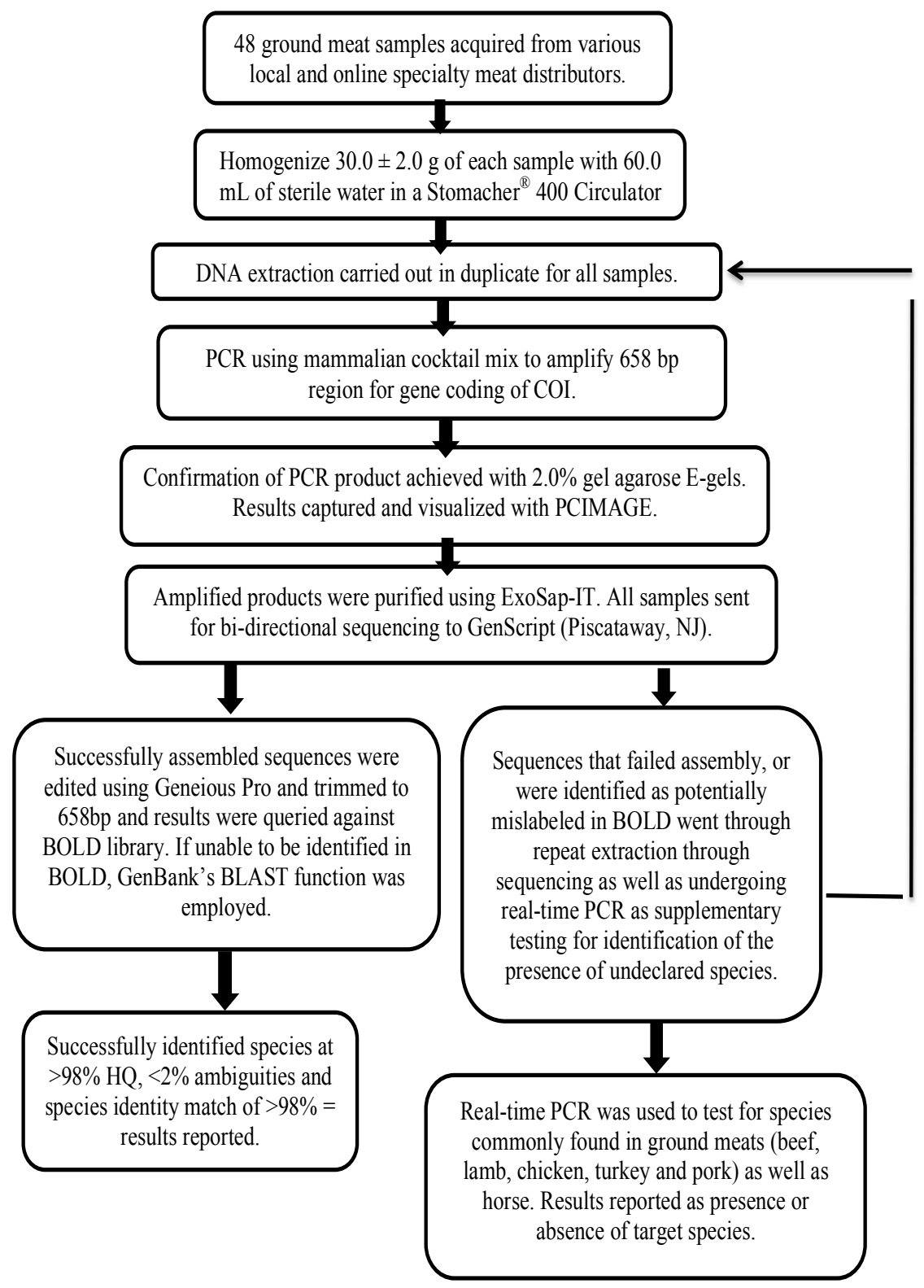


Figure 2: Diagram of sample collection through analysis of ground meat

\subsection{Sample Collection}

A total of 48 ground meat samples were purchased from 3 local supermarkets, 1 local butcher and 5 online specialty meat distributors for use in this study (Figure 3). These samples represented 15 different meat types, including products labeled as antelope $(n=1)$, beef $(n=9)$, bison $(n=5)$, black bear $(n=1)$, duck $(n=1)$, elk $(n=3)$, emu $(n=1)$, goat $(n=1)$, kangaroo $(n=2)$, turkey $(n=7)$, veal $(n=2)$, lamb $(n=3)$, chicken $(n=4)$, pork $(n=6)$ and yak $(n=2)$.

Following collection, all of the products were catalogued and stored at $-80^{\circ} \mathrm{C}$ until used. Prior to sampling, products were thawed overnight at $4^{\circ} \mathrm{C}$. For each sample, a total of $30.0 \pm 2.0 \mathrm{~g}$ was aseptically removed using sterile forceps and weighed into a separate, sterile 24-oz Whirl-pak ${ }^{\circledR}$ bag (Nasco, Salida, CA). Care was taken at this stage not to cross-contaminate samples; any equipment, utensils, or containers used were sterile and either disposable or flame sterilized with ethanol prior to the preparation of each sample. Each container (e.g., stomacher bag, microcentrifuge tubes) containing a sample was labeled with its respective sample ID at all times and covered when not in use. Approximately $60.0 \mathrm{ml}$ of sterile water was added to each Whirl-pak bag containing a sample and the bag was placed in a Stomacher ${ }^{\circledR} 400$ Circulator (Seward, Davie, FL) at $230 \mathrm{rpm}$ for $120 \mathrm{~s}$ (Okuma and Hellberg 2014). Two 10 mg subsamples of the solid portion of each homogenized product were then placed into two separate $1.5 \mathrm{ml}$ microcentrifuge tubes labeled with the sample ID for DNA extraction. 


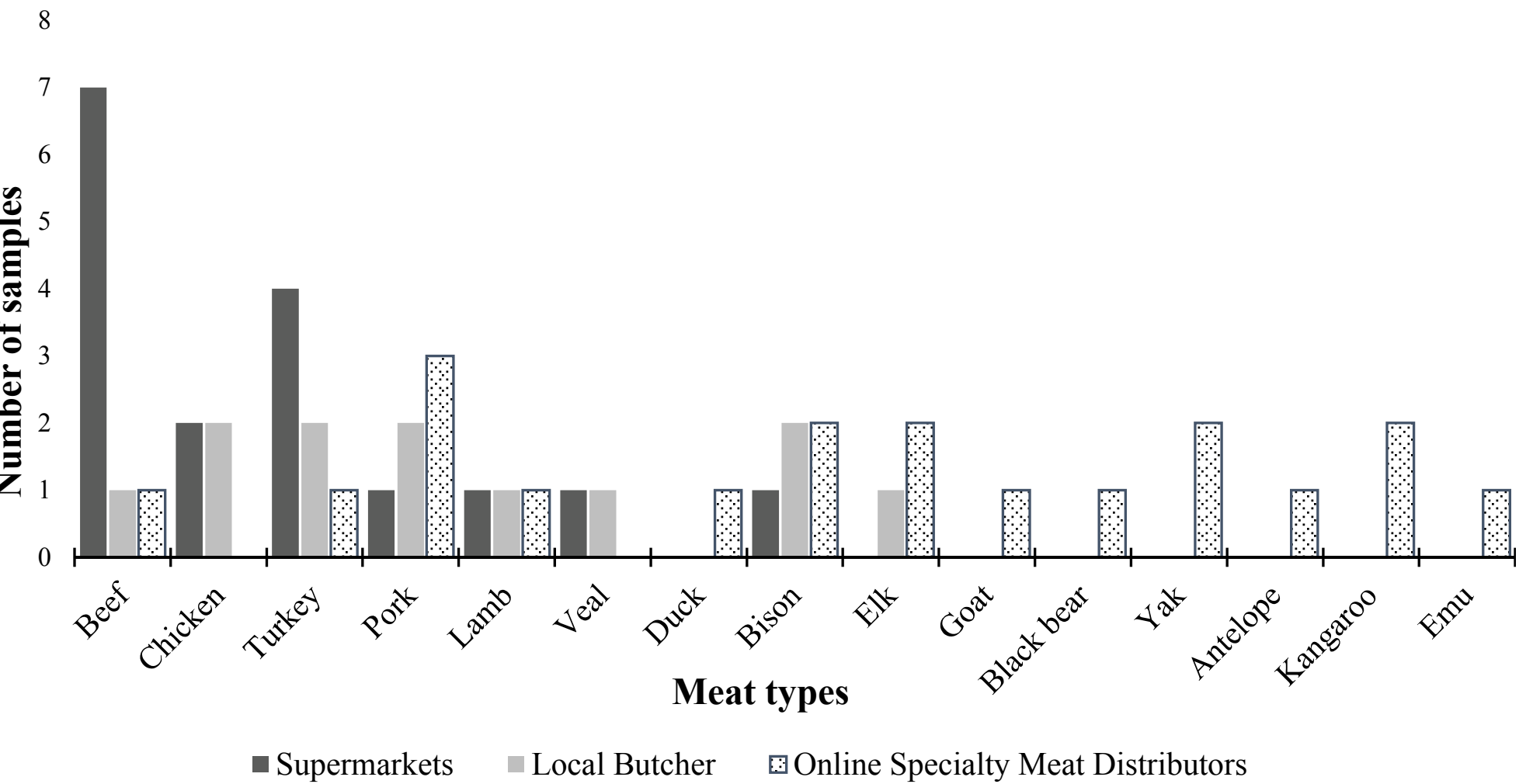

Figure 3: Summary of meat types purchased for this study, separated by retail source 


\subsection{DNA Extraction}

DNA extraction was carried out in duplicate for all ground meat samples using a modified version of the DNeasy Blood and Tissue Kit (Qiagen, Valencia, CA), SpinColumn protocol, according to modifications described in Handy and others (2011b). Following sample collection as described above, the tissue samples were lysed with $50 \mu 1$ Buffer ATL and $5.56 \mu 1$ Proteinase $\mathrm{K}$ over a period of $1-3 \mathrm{~h}$ at $56^{\circ} \mathrm{C}$ with vortexing at 30 min increments. Tissue was incubated until completely lysed. Lysate was checked so that its consistency was viscous but not gelatinous, and no particles of meat were present. To collect condensate, the microcentrifuge tubes were briefly spun down using a centrifuge. Next, using only filtered pipette tips, $55.6 \mu 1$ Buffer AL and 55.6 $\mu 1$ 95\% ethanol were added to each sample tube and the tubes were vortexed again immediately. If precipitate formed, vigorously shaking or vortexing helped dissolve it. The solution was next pipetted into DNeasy Mini spin columns, each placed inside a $2 \mathrm{ml}$ collection tube, and centrifuged at $8000 \mathrm{rpm}$ for $1 \mathrm{~min}$. Next, the spin columns were placed in new $2 \mathrm{ml}$ collection tubes and discard flow was emptied into a specifically designated waste container. Next, $140 \mu 1$ of AW1 buffer was added to the spin column and the mixture was centrifuged for $1 \mathrm{~min}$ at $8000 \mathrm{rpm}$. Again, the flow through was discarded in a specially designated waste container. The spin columns were placed in new collection tubes, followed by a second wash with $140 \mu 1$ of AW2 buffer and centrifugation for 3 min at $14,000 \mathrm{rpm}$ to dry the membrane. The columns were then transferred to a sterile, labeled $1.5 \mathrm{ml}$ microcentrifuge tube prior to adding $50 \mu 1$ of $\mathrm{AE}$ buffer that was preheated to $37^{\circ} \mathrm{C}$. The buffer was added directly onto the center of the membrane, but without physically touching the membrane itself. The samples were incubated at room 
temperature for $1 \mathrm{~min}$, then centrifuged for $1 \mathrm{~min}$ at $8,000 \mathrm{rpm}$. The collected elution contained the DNA template. The DNA was either used immediately, or stored at $-20^{\circ} \mathrm{C}$. A rack for storage of tubes was adequately labeled with initials, date and specificity of contents. A reagent blank with no tissue added was included alongside each set of extracted samples. Before and after all extraction runs, the bench area and equipment was thoroughly cleaned with DNA Away (Thermo Scientific, Waltham, MA)

\subsection{PCR and Sequencing}

Prior to beginning PCR, the number of reactions required, plus approximately $10 \%$ loss was calculated for accurate reconstitution of primer mixture. Required supplies were placed in the PCR hood, and treated with UV light for 20 min, allowing for sterilization prior to starting the procedure. The mammalian primer cocktails described by Ivanova and others (2012) were used to amplify a 658-bp region of the mitochondrial gene COI. PCR was carried out as described in Ivanova and others (2012) except that OmniMix HS (Cepheid, Sunnyvale, CA) lyophilized PCR reagent beads were used in place of adding individual reagents and the total reaction volume was increased to $25 \mu 1$. Each reaction included the following: 0.5 OmniMix HS PCR bead, $22.5 \mu 1$ molecular grade water, $0.25 \mu 1$ of each $10 \mu \mathrm{M}$ primer cocktail (Table 3), and $2 \mu 1$ of DNA. A nontemplate control (NTC) of $2 \mu 1$ sterile water was included with set of samples run. 
Table 3: PCR Master Mix reagent guide

\begin{tabular}{llc}
\hline Component & $\begin{array}{l}\text { Volume for } \mathbf{1} \\
\text { reaction }\end{array}$ & ${\text { Volume for } 5 \text { reactions }^{\mathbf{b}}}$ \\
\hline OmniMix Bead $^{\mathrm{a}}$ & $0.5 \mathrm{bead}$ & $3 \mathrm{beads}$ \\
Sterile water & $22.5 \mu \mathrm{l}$ & $135 \mu \mathrm{l}$ \\
$10 \mu \mathrm{M}$ Fwd Primer Cocktail & $0.25 \mu \mathrm{l}$ & $1.5 \mu \mathrm{l}$ \\
$10 \mu \mathrm{M}$ Rev Primer Cocktail & $0.25 \mu \mathrm{l}$ & $1.5 \mu \mathrm{l}$ \\
\hline
\end{tabular}

${ }^{\mathrm{a}}$ Each bead in a $0.5 \mathrm{ml}$ tube contains enough reagents to perform two $25 \mu \mathrm{l}$ PCR amplifications. When working with OmniMix beads add one additional bead for larger sample sizes.

${ }^{\mathrm{b}}$ Includes a $10 \%$ reagent excess to account for volume lost during pipetting

Cycling conditions were followed according to Ivanova and others (2012): $94^{\circ} \mathrm{C}$ for $2 \mathrm{~min} ; 5$ cycles of $94^{\circ} \mathrm{C}$ for $30 \mathrm{~s}, 50^{\circ} \mathrm{C}$ for $40 \mathrm{~s}$, and $72^{\circ} \mathrm{C}$ for $1 \mathrm{~min} ; 35$ cycles of $94^{\circ} \mathrm{C}$ for $30 \mathrm{~s}, 55^{\circ} \mathrm{C}$ for $40 \mathrm{~s}$, and $72^{\circ} \mathrm{C}$ for $1 \mathrm{~min}$; and a final extension step at $72^{\circ} \mathrm{C}$ for $10 \mathrm{~min}$. Thermocycling was carried out with a Mastercycler nexus gradient thermal cycler (Eppendorf, Hauppauge, NY).

\subsubsection{Confirmation of PCR}

Designated lab coats and glasses were always worn in the post PCR area to minimize any chance of cross contamination. Confirmation of PCR was achieved as described in Hellberg and others (2014), with slight modifications. PCR products $(4 \mu 1)$ were loaded along with sterile water $(16 \mu 1)$ onto pre-cast $2.0 \%$ agarose E-gels (Life Technologies, Carlsbad, CA) and run for 6-10 min using an E-Gel iBase Power System (Life Technologies). Results were captured using Foto/Analyst Express (Fotodyne, Hartland, WI) combined with Transilluminator FBDLT-88 (Fisher Scientific, Waltham, MA) and visualized with PCIMAGE (version 5.0.0.0 Fotodyne, Hartland, WI). 


\subsubsection{Preparation for Sequencing}

Amplified products were purified using ExoSAP-IT (Affymetrix, Santa Clara, CA) according to the manufacturer's instructions. After PCR and gel electrophoresis, a tube was prepared for each sample containing $5 \mu \mathrm{l}$ of PCR product and $2 \mu \mathrm{l}$ of ExoSAPIT. Cycling conditions were followed according to Handy and others (2011b): $37^{\circ} \mathrm{C}$ for $15 \mathrm{~min}, 80^{\circ} \mathrm{C}$ for $15 \mathrm{~min}$, followed by an indefinite hold at $10^{\circ} \mathrm{C}$. Once the program was completed, the purified product was placed in the $-20^{\circ} \mathrm{C}$ freezer until preparation for sequencing. The sequencing preparation instructions were followed according to GenScript sequencing guidelines. Each purified product occupied two wells, one for forward sequencing and one for reverse sequencing. Sterile molecular grade water $(7 \mu 1)$ was transferred to each well of sequencing plate/strips. Next, $5 \mu l$ of the forward M13 primer [M13F(-21) TGTAAAACGACGGCCAGT ] $(5 \mu \mathrm{M})$ was added to each well that was going to undergo forward sequencing. Then, $5 \mu 1$ of the reverse M13 primer [M13R(-27) CAGGAAACAGCTATGAC ] (5 $\mu \mathrm{M})$ was added to each well that was going to undergo reverse sequencing. Finally, $3 \mu 1$ of the purified PCR product was added to the forward sequencing well and $3 \mu 1$ to the reverse sequencing well. The samples were then sent to GenScript (Piscataway, NJ) for bi-directional sequencing using BigDye Terminator v3.1 Cycle Sequencing Kit (Life Technologies) and a 3730xl Genetic Analyzer (Life Technologies). ${ }^{\mathrm{c}}$ Agar-gel immunodiffusion

\subsection{Sequence Analysis}

Raw sequence files were assembled and edited using Geneious R7 (Biomatters Ltd., Auckland, New Zealand). The resulting consensus sequences were then aligned using ClustalW and trimmed to the 658-bp COI DNA barcode region. The consensus 
sequence lengths, \% high quality bases (HQ\%), and number of ambiguities were recorded. Samples were considered to have been successfully sequenced if they met the following requirements outlined in Handy and others (2011a): bidirectional sequences $\geq$ 500 bp in length with $<2 \%$ ambiguities or a single-read $\geq 500$ bp in length with $\geq 98 \%$ HQ. Consensus sequences were queried against the Barcode of Life Database (BOLD) species identification tool using the Species Level Barcode Records option, to determine the top species match. If a species was unable to be identified using BOLD, a search was conducted in GenBank using the Basic Local Alignment Search Tool (BLAST). The top species matches in GenBank, along with Query Coverage (\%) and \% Identity were recorded. Once each species was identified using BOLD or BLAST, its common name was determined using the Encyclopedia of Life [(EOL) (http://eol.org/)]. Any samples that failed sequencing or were initially identified as mislabeled underwent repeat DNA extraction, PCR, and sequencing. Samples that initially failed sequencing were also tested with real-time PCR, as described below, due to the possibility of a species mixture.

\subsection{Real-Time PCR}

Real-time PCR was used to test for the presence of commonly found species in ground meats (beef, lamb, chicken, turkey, and pork) as well as horse, as described in Okuma and Hellberg (2014). Amplification was carried out using a Rotor-Gene ${ }^{\circledR} \mathrm{Q}$ Cycler (Qiagen, Germantown, MD). Each reaction tube was labeled with their respective sample ID, and the reagents listed in Table $\mathbf{4}$ were added to each tube. 
Table 4: Real-time PCR components

\begin{tabular}{lc}
\hline Reagent & Volume per $\mathbf{2 5} \boldsymbol{\mu l}$ reaction $(\boldsymbol{\mu l})$ \\
\hline $\mathrm{iQ}^{\mathrm{TM}} \mathrm{SYBR}^{\circledR}$ Green Supermix $(2 \mathrm{X})$ & 12.5 \\
Forward species-specific primer & 1.0 \\
Reverse species-specific primer & 1.0 \\
DNA template & 2.0 \\
Sterile $\mathrm{H}_{2} \mathrm{O}$ & 8.5 \\
Total reaction volume & 25 \\
\hline
\end{tabular}

The final primer concentrations were $0.16 \mu \mathrm{M}$ for beef, $0.25 \mu \mathrm{M}$ for lamb, $0.2 \mu \mathrm{M}$ for chicken and turkey, and $0.3 \mu \mathrm{M}$ for pork and horse. Positive DNA controls for each meat species were prepared in three 10 -fold serial dilutions $\left(10^{-1}, 10^{-2}\right.$ and $\left.10^{-3}\right)$ using Tris-EDTA buffer, pH 8.0 (BioExpress, Kaysville, UT) and were included in each PCR run. A nontemplate control (NTC) containing sterile water in place of DNA was also run along with every set of samples. Thermocycler settings for specific animal species were followed according to Yancy and others (2009) and are described in Table 5.

Table 5: Real-time PCR thermocycler settings for beef, chicken, turkey, pork, lamb and horse.

\begin{tabular}{|c|c|c|c|c|c|}
\hline \multirow{2}{*}{$\begin{array}{c}\text { Meat } \\
\text { Species }\end{array}$} & \multirow{2}{*}{$\begin{array}{c}\text { Polymerase } \\
\text { Activation } \\
\text { and DNA } \\
\text { Denaturation }\end{array}$} & \multicolumn{3}{|c|}{ Amplification (50 Cycles) } & \multirow{2}{*}{$\begin{array}{l}\text { Melt Curve } \\
\text { Analysis }\end{array}$} \\
\hline & & Denaturation & Annealing & Extension & \\
\hline \multirow{3}{*}{$\begin{array}{c}\text { Beef, } \\
\text { lamb, } \\
\text { avians } \\
\text { (chicken, } \\
\text { turkey) }\end{array}$} & $94^{\circ} \mathrm{C}$ for & \multirow{3}{*}{$\begin{array}{l}94^{\circ} \mathrm{C} \text { for } \\
10 \mathrm{~s}\end{array}$} & \multirow{3}{*}{$\begin{array}{c}58.9^{\circ} \mathrm{C} \text { for } \\
15 \mathrm{~s}\end{array}$} & \multirow{3}{*}{$\begin{array}{c}72^{\circ} \mathrm{C} \text { for } \\
40 \mathrm{~s}\end{array}$} & $\operatorname{Beef}\left(82.5^{\circ}\right)$ \\
\hline & \multirow[t]{2}{*}{$2 \mathrm{~min}$} & & & & $\operatorname{Lamb}\left(79^{\circ} \mathrm{C}\right)$ \\
\hline & & & & & $\begin{array}{c}\text { - Chicken/Turkey } \\
\left(80^{\circ} \mathrm{C}\right)\end{array}$ \\
\hline Horse & $94^{\circ} \mathrm{C}$ for & \multirow{2}{*}{$94^{\circ} \mathrm{C}$ for $50 \mathrm{~s}$} & $\begin{array}{l}61^{\circ} \mathrm{C} \text { for } \\
50 \mathrm{~s}\end{array}$ & \multirow{2}{*}{$\begin{array}{c}72^{\circ} \mathrm{C} \\
\text { for } 1 \mathrm{~min}\end{array}$} & Final \\
\hline Pork & $2 \min$ & & $\begin{array}{c}55^{\circ} \mathrm{C} \text { for } \\
50 \mathrm{~s} \\
\end{array}$ & & $\begin{array}{l}\text { Extension } \\
72^{\circ} \mathrm{C} \text { for } 5 \mathrm{~min}\end{array}$ \\
\hline
\end{tabular}


Melt curve analysis was completed at the end of each run. Results were determined to be positive if at least one of the subsamples tested had a cycle threshold $(\mathrm{Ct})$ value for the meat species being tested and had a melting temperature within $0.5^{\circ} \mathrm{C}$ of the average positive control melting temperatures for that run (Okuma and Hellberg 2014). Results were qualitative and reported as presence or absence of the target species.

\section{Results and Discussion}

\subsection{DNA Barcoding Results}

Of the 48 samples collected in this study, 39 samples were successfully bidirectionally sequenced to assemble a COI barcode for both replicates prepared during DNA extraction. The average sequence length for these samples was $651 \pm 19 \mathrm{bp}$, the average ambiguity was $0.14 \pm 0.54 \%$ and the average $\mathrm{HQ} \%$ was $87.5 \pm 12.0 \%$. A total of 9 samples showed sequencing failure in one or both replicates. These samples underwent repeat DNA extraction and sequencing in duplicate, as well as testing with real-time PCR in case of a species mixture. This follow-up testing resulted in successful sequencing for both replicates in 7 of the samples and successful sequencing for only one replicate in 2 of the samples. Based on the combination of sequencing and real-time PCR results, one of these samples, labeled as yak, was found to contain only one species and the remaining samples were found to contain multiple species. The samples found to contain multiple species are discussed in detail in the following section.

Among the 39 samples found to contain just one species, sequence queries against BOLD allowed for positive identification at the species level for 38 of the samples with pairwise similarities of $>99.7 \%$ (Table 6). One of the samples labeled as kangaroo 
could not be identified using BOLD and was instead queried against GenBank, which resulted in a $100 \%$ genetic match to Western grey kangaroo (Macropus fuliginosus). All of these samples were found to be correctly labeled except one product purchased from an online specialty meat distributor which was labeled as yak burgers but identified as cattle (Bos taurus)/zebu cattle (Bos indicus). Yak and cattle have been crossbred resulting in a species resembling a yak, known as a female dzomo or male dzo. While the females are used for further reproduction and milk production, the males are sterile and slaughtered for meat. However this has only been confirmed to be occurring in Nepal, Mongolia and Tibet (Qi and others 2010). This identification was confirmed following repeat DNA extraction and sequencing. This distributor sells ground beef products for US $\$ 22.00 / \mathrm{kg}$ compared to their yak burgers which retail for US $\$ 43.98 / \mathrm{kg}$. This is a case where economic gain is a likely cause of mislabeling, as substituting the lower-cost beef for yak can result in a two-fold profit for the company. Among the correctly labeled samples, 13 were purchased from online specialty meat distributors, 9 were purchased from a local butcher, and 16 were purchased from local supermarkets.

Table 6: Results for samples found to contain one species. Species were identified using the Barcode of Life Database (BOLD), except where otherwise noted.

\begin{tabular}{lccl}
\hline Product label & $\begin{array}{c}\text { Samples } \\
(\mathbf{n})\end{array}$ & $\begin{array}{c}\text { Genetic } \\
\text { similarity }\end{array}$ & Top species match \\
\hline Antelope & 1 & $99.7 \%$ & $\begin{array}{l}\text { Nilgai (Boselaphus } \\
\text { tragocamelus) }\end{array}$ \\
Beef & 9 & $100.0 \%$ & Cattle (Bos taurus) \\
Bison/Buffalo & 4 & $99.9-100.0 \%$ & $\begin{array}{l}\text { American bison } \\
\text { (Bison bison) }\end{array}$
\end{tabular}




\begin{tabular}{|c|c|c|c|}
\hline Chicken & 3 & $99.8-100.0 \%$ & $\begin{array}{l}\text { Chicken/Red } \\
\text { junglefowl (Gallus } \\
\text { gallus) }\end{array}$ \\
\hline Duck & 1 & $100.0 \%$ & $\begin{array}{l}\text { Mallard (Anas } \\
\text { platyrhynchos) }\end{array}$ \\
\hline Elk & 3 & $99.8-100.0 \%$ & $\begin{array}{l}\text { Red deer (Cervus } \\
\text { elaphus) }\end{array}$ \\
\hline Emu & 1 & $99.8 \%$ & $\begin{array}{l}\text { Emu (Dromaius } \\
\text { novaehollandiae) }\end{array}$ \\
\hline Goat & 1 & $100.0 \%$ & $\begin{array}{l}\text { Domestic goat } \\
\text { (Capra hircus) }\end{array}$ \\
\hline Kangaroo & 1 & $100.0 \%{ }^{\mathrm{a}}$ & $\begin{array}{l}\text { Western grey } \\
\text { kangaroo } \\
\text { (Macropus } \\
\text { fuliginosus) }\end{array}$ \\
\hline Lamb & 2 & $100.0 \%$ & $\begin{array}{l}\text { Domestic sheep } \\
\text { (Ovis } \\
\text { aries)/Mouflon (O. } \\
\text { aries musimon) }\end{array}$ \\
\hline Pork & 3 & $99.8-100.0 \%$ & $\begin{array}{l}\text { Wild boar }(S . \\
\text { scrofa }^{\mathrm{b}}\end{array}$ \\
\hline Turkey & 4 & $99.9-100.0 \%$ & $\begin{array}{l}\text { Wild turkey } \\
\text { (Meleagris } \\
\text { gallopavo) }\end{array}$ \\
\hline Veal & 2 & $100.0 \%$ & Cattle (B.taurus) \\
\hline Wild Boar & 3 & $99.8-100.0 \%$ & $\begin{array}{l}\text { Wild boar (Sus } \\
\text { scrofa) }\end{array}$ \\
\hline Yak $^{\mathrm{c}}$ & 1 & $99.9-100.0 \%$ & $\begin{array}{l}\text { Cattle (B. taurus) } \\
\text { zebu cattle (Bos } \\
\text { indicus) }\end{array}$ \\
\hline
\end{tabular}


${ }^{\text {a }}$ The sample sequences were not available in BOLD and were instead identified using BLAST. The \% identity from GenBank is given

${ }^{\mathrm{b}}$ Domestic pig (Sus scrofa domesticus) is a subspecies of wild boar

${ }^{\mathrm{c}}$ Sample identified as mislabeled

\subsection{Samples Identified to Contain Mixed Species}

As mentioned in section 4.1, 9 of the samples tested in this study were found to contain multiple species (Table 7). These samples were tested with both DNA barcoding and real-time PCR, and consisted of products labeled as turkey $(\mathrm{n}=3)$, lamb $(\mathrm{n}=1)$, black bear $(n=1)$, chicken $(n=1)$, bison $(n=1)$, kangaroo $(n=1)$ and yak $(n=1)$. Two of the three samples labeled as ground turkey (K21 and K23) were purchased from a local butcher and one sample labeled as turkey burgers (K34) was purchased from an online specialty meat distributor. All three samples listed USA as country of origin. DNA barcoding indicated a species identity match of $100 \%$ to wild turkey (Meleagris gallopavo) for the successful sequencing replicates originating from the two samples from the local butcher, while the sample from the online specialty meat distributor had one sequencing replicate with a $100 \%$ match to wild turkey and another replicate with a $100 \%$ match to chicken/red junglefowl (Gallus gallus). Additional testing with real-time PCR revealed multiple undeclared species in these products. In addition to confirming the presence of turkey in all three products, real-time PCR results for the turkey samples from the local butcher (K21 and K23) revealed the presence of lamb, chicken, and beef, while the sample from the online specialty meat distributor (K34) was positive for lamb and chicken. The undeclared species that were detected in the turkey samples with realtime PCR were either more expensive than turkey (beef and lamb) or considered about the same relative cost (chicken) as turkey, indicating that economic fraud was not the 
cause of mislabeling (USDA 2014a; USDA 2014b). Both the local butcher and the online specialty meat distributor sell several varieties of ground meats, including beef, chicken and lamb. The presence of multiple species commonly found in ground meats, and the fact that these retailers sell the species detected suggests the possibility of crosscontamination at the processing facility. Unintentional mislabeling may occur when several species are ground on the same manufacturing equipment, without proper cleaning in between samples (Hsieh and others 1995).

The product labeled as ground chicken (K27) that was found to contain multiple species was purchased from a local supermarket and listed USA as the country of origin. This sample was identified as chicken in BOLD with a $100 \%$ species identity match. However, real-time PCR indicated the presence of beef, turkey and lamb in addition to chicken. Because the cost of the undeclared species is typically higher than or similar to the cost of chicken (USDA 2014a; USDA 2014b), economic gain is not suspected here and, similar to the mislabeled turkey products discussed above, the mislabeling is more likely due to cross-contamination at the processing facility. Importantly, the presence of mammalian species in products labeled as only containing poultry is concerning for individuals that are intentionally avoiding these species due to a meat allergy (Restani and others 2009). While meat allergies are uncommon, they can have serious health consequences, such as hives, asthma or even anaphylactic shock (Restani and others 2009).

The sample labeled as yak burgers (K31) that was found to contain multiple species was purchased from an online specialty meat distributor and listed USA as the country of origin. The sequencing results for this sample initially showed a top species 
match to cattle with $100 \%$ genetic similarity; however, following repeat DNA extraction and sequencing, the top species match was to guanaco (Lama guanicoe) with $100 \%$ similarity, with secondary species matches of $99.2-99.4 \%$ to llama (Lama glama) and alpaca (Lama pacos). Guanaco, llama, and alpaca likely cannot be differentiated using the COI barcode region due to a history of interbreeding and domestication (Barreta and others 2013). Real-time PCR results confirmed the presence of beef in the sample, with no additional species detected. The use of guanaco/llama/alpaca does not represent a case of economic gain, as the cost of ground llama and ground alpaca sold from this online specialty meat distributor (US $\$ 21.89 / \mathrm{kg}$ ) is greater than the cost of ground yak (US $\$ 19.69 / \mathrm{kg}$ ) sold by the same distributor. However, the use of beef in the product would be an instance of economic fraud, as the average price per kilogram for ground beef (US $\$ 9.14 / \mathrm{kg}$ ) (USDA 2014a) is about half that of ground yak.

The mixed-species sample labeled as black bear burgers (K30) was purchased from an online specialty meat distributor and listed USA as the country of origin. Sequencing results identified the sample as American beaver (Castor canadensis) with a $100 \%$ species match. Additional testing with real-time PCR on this product revealed the presence of pork in the sample as well. Interestingly, black bear burgers were previously implicated in a case of labeling fraud uncovered by the FDA (FDA 2011). In 2011, the FDA issued a warning letter to an online specialty meat distributor on multiple accounts of food fraud stating that the black bear (Ursus americanus) burgers being sold were found to contain elk/red deer (Cervus sp.) and that products labeled as black bear steaks were, in actuality, brown bear (Ursus arctos). Similarly, the black bear burgers tested in the current study were not labeled properly and represent a case of food fraud. Since the 
cost of ground beaver offered by the same online specialty meat distributor was equivalent to the cost of ground black bear, this may represent a case of substitution due to mishandling or supply shortages. Alternatively, the presence of pork in the product does indicate economic fraud by mixing in a lower-cost meat. This online specialty meat distributor sells both black bear burgers and ground beaver meat for US $\$ 21.89 / \mathrm{kg}$, whereas the average cost of pork is listed at US $\$ 9.13 / \mathrm{kg}$ (USDA 2014a), suggesting that substitution for economic gain is a viable explanation.

The mixed-species sample labeled as ground kangaroo (K38) was also obtained through an online specialty meat distributor and listed a country of origin of Australia. This sample could not be identified at the species level in BOLD, but showed a top match to Western grey kangaroo when searched in GenBank, with a genetic similarity of $96 \%$. Real-time PCR results also indicated the presence of beef in the sample. The mixing of beef with kangaroo meat could be economically motivated or could be due to crosscontamination during processing. This online specialty meat distributor sells ground kangaroo for US $\$ 19.76 / \mathrm{kg}$ compared with ground beef at US $\$ 9.90 / \mathrm{kg}$, resulting in a potential profit to be made by mixing in the lower-cost beef with the more expensive kangaroo meat.

Two of the samples with multiple species detected were found to contain horsemeat (Table 7). These samples were labeled as ground bison (K35) and ground lamb meat (K29) and were purchased from two different online specialty meat distributors. The sample labeled as ground bison had a top match in BOLD to American elk (Cervus canadensis) with 97.8\% genetic similarity, and real-time PCR also revealed the presence of beef, pork, and horse. The sample labeled as ground lamb was identified 
as lamb/sheep (Ovis aries) in BOLD with 100\% genetic similarity and real-time PCR revealed the presence of pork and horse in addition to lamb. The sample labeled as lamb listed the USA as its country of origin, whereas the sample labeled as bison listed Canada as its country of origin. In addition to being mislabeled, these two samples are also in violation of U.S. regulations against the sale of horsemeat. In 2007, nine years after California voters first passed Proposition 6, which banned the slaughter of horses and similar equines for sale for their meat for human consumption, Congress passed the American Horse Slaughter Prevention Act, prohibiting the sale of equines including horses and mules for human consumption under the Federal Meat Inspection Act (FMIA) (Library of Congress 2011; Potter 2012). This includes the prohibition of shipping, transporting, moving, delivering, receiving, possessing, purchasing, selling or donation of horses and other equines for human consumption (Library of Congress 2011). Along with a nationwide ban on selling horsemeat for human consumption, some states (including California) have a law of repugnance which prevents selling any part of a horse for human consumption (Roth 2007; CPC 1998).

Overall, mislabeling was found to be most common in products purchased from online specialty meat distributors, which showed a $35 \%$ rate of mislabeling and included products labeled as black bear and yak burgers. The next-highest rate of mislabeling (18\%) was found in samples purchased from a local butcher, for which two samples labeled as ground turkey were identified as mislabeled. Local supermarkets showed the lowest rate of mislabeling (5.8\%), with just one product labeled as ground chicken found to be mislabeled. 


\subsection{This Study as Compared to Previous Studies}

The rate of mislabeling found in the current study of $21 \%$ is slightly higher than that found by a previous U.S. study, which reported a mislabeling rate of $16.6 \%$ for ground meats (Hsieh and others 1995). A possible reason for the difference in these rates is that Hsieh and others (1995) did not examine game meats, which showed a higher rate of mislabeling in the current study (27.8\%) compared to the mislabeling rate for nongame meats (16.7\%). Another possible reason is difference in sample size. While this study examined 48 ground meat products, the Florida study sampled 806 ground meat products. Interestingly, the previous study reported that products labeled as ground beef and veal were most likely to be mislabeled or contain undeclared species, whereas in the current study, none of the products labeled as beef or veal were found to be mislabeled. However, in both studies beef was found to be a commonly undeclared species detected in products. In this study, of the 9 mislabeled samples containing mixed species, 6 were found to contain beef. Besides beef, common undeclared species found in both studies were lamb, poultry and pork. Similar to the current study, previous studies have also reported the presence of horse as an undeclared ingredient (Flores-Munguia and others 2000; Ayaz and others 2006). For example, a study conducted in Mexico reported horse in $39 \%$ of hamburger samples labeled as containing $100 \%$ beef (Flores-Munguia and others 2000). The authors noted that in Mexico, horse is of lower quality and value than beef and it is regulated less than other meat species, providing the potential for it to be mixed into higher-priced ground meats. Studies conducted in South Africa have also reported widespread mislabeling of ground meats, with products containing undeclared pork and lamb, as well as high rates of mislabeling of game meats (D'Amato and others 
2013). Similar to the current study, previous instances of mislabeling have been attributed to factors such as economic incentive, human error, improper identification and labeling of game meat species, and insufficient cleaning techniques of equipment that multiple species are ground on. 
Table 7: Combination of DNA barcoding and real-time PCR results for samples found to contain multiple species

\begin{tabular}{|c|c|c|c|c|c|c|c|c|c|}
\hline \multirow{2}{*}{$\begin{array}{l}\text { Sample } \\
\text { number }\end{array}$} & \multirow{2}{*}{$\begin{array}{l}\text { Product } \\
\text { label }\end{array}$} & \multirow{2}{*}{$\begin{array}{l}\text { Top species match } \\
\text { with DNA barcoding }\end{array}$} & \multirow{2}{*}{$\begin{array}{l}\text { Genetic } \\
\text { similarity }\end{array}$} & \multicolumn{6}{|c|}{ Real-time PCR results } \\
\hline & & & & Beef & Pork & Turkey & Sheep/Lamb & Chicken & Horse \\
\hline K30 & $\begin{array}{l}\text { Black } \\
\text { bear }\end{array}$ & $\begin{array}{l}\text { American beaver } \\
\text { (Castor canadensis) }\end{array}$ & $100.0 \%$ & - & + & - & - & - & - \\
\hline K35 & Bison & $\begin{array}{l}\text { American elk (Cervus } \\
\text { canadensis) }\end{array}$ & $97.8 \%$ & + & + & - & - & - & + \\
\hline K27 & Chicken & $\begin{array}{l}\text { Chicken/Red } \\
\text { junglefowl (Gallus } \\
\text { gallus) }\end{array}$ & $100.0 \%$ & + & - & + & + & + & - \\
\hline K38 & Kangaroo & $\begin{array}{l}\text { Western grey kangaroo } \\
\text { (Macropus fuliginosus) }\end{array}$ & $96.0 \%$ & + & - & - & - & - & - \\
\hline K29 & Lamb & $\begin{array}{l}\text { Domestic sheep (Ovis } \\
\text { aries)/Mouflon }(O . \\
\text { aries musimon) }\end{array}$ & $100.0 \%$ & - & + & - & + & - & + \\
\hline K21 & Turkey & $\begin{array}{l}\text { Wild turkey (Meleagris } \\
\text { gallopavo) }\end{array}$ & $100.0 \%$ & + & - & + & + & + & - \\
\hline K23 & Turkey & $\begin{array}{l}\text { Wild turkey } \\
\text { (M.gallopavo) }\end{array}$ & $100.0 \%$ & + & - & + & + & + & - \\
\hline K34 & Turkey & $\begin{array}{l}\text { Wild turkey } \\
\text { (M.gallopavo); Chicken } \\
\text { (G. gallus) }\end{array}$ & $100.0 \% ; 100.0 \%$ & - & - & + & + & + & - \\
\hline K31 & Yak & $\begin{array}{l}\text { Guanaco (Lama } \\
\text { guanicoe); Cattle (Bos } \\
\text { taurus) }\end{array}$ & $100.0 \% ; 100.0 \%$ & + & - & - & - & - & - \\
\hline
\end{tabular}




\section{Conclusions}

This study indicated the presence of mislabeling in ground meat products sold on the U.S. commercial market. The majority of mislabeled products, including two samples found to contain horsemeat, were acquired from online specialty meat distributors, with only one mislabeled sample acquired from a supermarket. Despite government regulations in place to prevent misbranding of food products, it is apparent that some ground meat products are mislabeled and, in some cases, contain multiple species. The overall trends for mislabeling found in this study indicate the possibility of lower-cost species being either intentionally mixed in with higher-cost species for economic gain or being unintentionally mixed in with higher cost species due to crosscontamination in the processing facility. The results of this study indicate the importance of continuous monitoring of commercial ground meat products for mislabeling, especially in the case of online specialty meat distributors.

\section{Recommendations for Future Studies}

The results of this study were similar to other international studies, suggesting that mislabeling of ground meat products is a universal occurrence. While this study did collect ground meats from across the United States, the majority of meats that were ordered from online distributors were exotic species, potentially increasing chances for that segment of suppliers to have a higher rate of mislabeling compared to supermarkets, in which the ground meat that was purchased were domestic species. Results have shown conclusive evidence that mislabeling is occurring among some U.S. ground meat distributors, and future studies should be designed to comprehensively compare the 
percent of mislabeled products from a wide range of supermarkets, online suppliers, and butcher-type facilities. This information would be beneficial to the suppliers by making them aware of GMPs that can be improved upon, such as improving the cleaning of equipment in between grinding products. The information is also helpful to consumers to make them aware of potential economic fraud that may be occurring when purchasing meat through online specialty meat distributors and even potential allergy concerns with the mixing of meats occurring on grinding equipment.

\section{References}

9 CFR § 301.2-2014. Misbranded and Definitions. In: Office USGP, editor. Title 9, Chapter III, Subchapter A, part 301.2. Washington, DC: U.S. Gov. Print. Off. CFR $\S \S 352-362$. 2000. Animals and animal products. Washington, DC: U.S. U.S. Gov. Print. Off.; 2000December 20, 2014] Available from: http://www.gpo.gov/fdsys/pkg/CFR-2000-title9-vol1/content-detail.html

21 CFR $\S 12.2009$. Meat Inspection. Washington, DC: U.S. Department of Health and Human Services; 2009 Available from: http://www.gpo.gov/fdsys/pkg/USCODE2011-title21/htm1/USCODE-2011-title21-chap12-subchapI-sec610.htm.

ACAAI. 2014. Meat allergy. American College of Allergy, Asthma \& Immunology.

Angel Sentandreu M, Sentandreu E. 2014. Authenticity of meat products: Tools against fraud. Food Res. Int. 60:19-29.

Ayaz Y, Ayaz ND, Erol I. 2006. Detection of species in meat and meat products using enzyme-linked immunosorbent assay. J. Muscle Foods 17(2):214-20.

Ballin NZ. 2010. Authentication of meat and meat products. Meat Sci. 86(3):577-87. 
Ballin NZ, Vogensen FK, Karlsson AH. 2009. Species determination - Can we detect and quantify meat adulteration? Meat Sci. 83(2):165-74.

Barreta J, Gutierrez-Gil B, Iniguez V, Saavedra V, Chiri R, Latorre E, Arranz JJ. 2013. Analysis of mitochondrial DNA in Bolivian llama, alpaca and vicuna populations: A contribution to the phylogeny of the South American camelids. Anim. Genet. 44(2):158-68.

BBC News. 2013. Findus beef lasagne contains up to $100 \%$ horsemeat, FSA says. In: BBC, editor. BBC News UK. Wales, UK: BBC.

Bremer JRA, Mejuto J, Greig TW, Ely B. 1996. Global population structure of the swordfish (Xiphias gladius L.) as revealed by analysis of the mitochondrial DNA control region. J. Exp. Mar. Bio. Ecol. 197(2):295-310.

Cawthorn D, Hoffman L. 2013. Is there horse in my wors? The World of Food Science: So. African-Food Sci.Technol.

Cawthorn D-M, Steinman HA, Hoffman LC. 2013. A high incidence of species substitution and mislabelling detected in meat products sold in South Africa. Food Control 32(2):440-9.

Chabad.org. 2014. Which animals are kosher. Chabad-Lubavitch Media Center. CPC. California Penal Code 598. California State Legislature; 1998 [Accessed 2014 November 8, 2014] Available from: http://www.leginfo.ca.gov/cgibin/displaycode? section $=$ pen $\&$ group $=00001-01000 \&$ file $=594-625 \mathrm{c}$.

D'Amato ME, Alechine E, Cloete KW, Davison S, Corach D. 2013. Where is the game? Wild meat products authentication in South Africa: A case study. Invest. Genet. $4(1)$. 
Everstine K. No Horse Meat Found in U.S. But Food Fraud Does Happen Boston, MA: Trustees of Boston University; 2013 [Accessed 2014 February 23] Available from: http://hereandnow.wbur.org/2013/02/28/horse-meat-scandal.

Everstine K, Spink J, Kennedy S. 2013. Economically motivated adulteration (EMA) of food: Common characteristics of EMA incidents. J. Food Prot. 76(4):723-35.

FDA. 2006. Title 21 - Food and Drugs. In: Services HaH, editor: U.S. Food and Drug Administration.

FDA. 2011. U.S. Food and Drug Administration: Warning letter 2/4/11. In: Inspections C, Enforcement, and Criminal Investigations, editor. Chicago, IL: U.S. Food and Drug Administration.

Flores-Munguia ME, Bermudez-Almada MC, Vazquez-Moreno L. 2000. A research note: Detection of adulteration in processed traditional meat products. J. Muscle Foods 11(4):319-25.

FSAI. FSAI survey finds horse DNA in some beef burger products. Dublin, Ireland: FSAI; 2013 [Accessed 2014 December 12, 2014] Available from: http://www.fsai.ie/news centre/press releases/horseDNA15012013.html.

Galimberti A, De Mattia F, Losa A, Bruni I, Federici S, Casiraghi M, Martellos S, Labra M. 2013. DNA barcoding as a new tool for food traceability. Food Res. Int. 50(1):55-63.

Gash C. 2013. South African meat snacks often mislabeled. New York, NY: The New York Times Company.

Handy SM, Deeds J, R., Ivanova NV, Hebert PDN, Hanner R, Ormos A, Weigt LA, Moore MM, Hellberg RS, Yancy HF. 2011a. Single laboratory validated method 
for DNA-barcoding for the species identification of fish for FDA regulatory compliance. Silver Spring, MD: U.S. Food and Drug Administration.

Handy SM, Deeds JR, Ivanova NV, Hebert PDN, Hanner RH, Ormos A, Weigt LA, Moore MM, Yancy HF. 2011b. A single-laboratory validated method for the generation of DNA barcodes for the identification of fish for regulatory compliance. Journal of AOAC International 94(1):201-10.

Hebert PDN, Cywinska A, Ball SL, deWaard JR. 2003. Biological identifications through DNA barcodes. P. Roy. Soc. B-Biol. Sci. 270(1512):313-21.

Hellberg RS, Kawalek MD, Van KT, Shen Y, Williams-Hill DM. 2014. Comparison of DNA extraction and PCR setup methods for use in high-throughput DNA barcoding of fish species. Food Anal. Method 7(10).

Hellberg RSR, Morrissey MT. 2011. Advances in DNA-based techniques for the detection of seafood species substitution on the commercial market. JALA 16(4):308-21.

Hsieh Y-HP, Woodward BB, Ho S-H. 1995. Detection of species substitution in raw and cooked meats using immunoassays. J. Food Prot. 58(5):555-9.

iBOL. 2014. What is DNA barcoding? In: Life IBo, editor. How DNA barcoding works and what it will do. Ontario, Canada: iBOL.

Ivanova NV, Clare EL, Borisenko AV. 2012. DNA barcoding in mammals. Methods Mol. Biol. 858:153-82.

Jacobs B. 2013. Horsemeat found in halal burgers at Lancashire schools. In: Telegraph L, editor. Weybridge, Surrey: Newsquest. 
Johns GC, Avise JC. 1998. A comparative summary of genetic distances in the vertebrates from the mitochondrial cytochrome b gene. Mol. Biol. Evol. 15(11):1481-90.

Johnson JR, Hagerman AD. 2012. USDA: U.S. importing more beef from Mexico. Washington, DC: U. S. Dep. Agric.

Lawrence F. 2014. Horsemeat scandal: Probe failure by authorities dates back to 1998 . London, England: Guardian News.

Library of Congress. American Horse Slaughter Prevention Act. Library of Congress:

USA.gov; 2011December 18, 2014] Available from: https://www.congress.gov/bill/112th-congress/house-bill/2966.

Lockley AK, Bardsley RG. 2000. DNA-based methods for food authentication. Trends Food Sci. Technol. 11(2):67-77.

Mackay IM, Arden KE, Nitsche A. 2002. Real-time PCR in virology. Nucleic Acids Res. 30(6):1292-305.

Marlin D, Kettlewell P, Parkin T, Kennedy M, Broom D, Wood J. 2011. Welfare and health of horses transported for slaughter within the European Union Part 1: Methodology and descriptive data. Equine Vet. J. 43(1):78-87.

McLoughlin KS. 2011. Microarrays for pathogen detection and analysis. Briefings Funct. Genomics 10(6):342-53.

Mitchell A. 2008. DNA barcoding demystified. Aust. J. Entomol. 47:169-73.

NSF. The 'new' phenomenon of criminal fraud in the food supply chain. Arlington, VA: National Science Foundation; 2014 Available from: http://www.nsf.org/newsroom pdf/NSF Food Fraud Whitepaper.pdf. 
Okuma TA, Hellberg RS. 2014. Identification of meat species in pet foods using a realtime polymerase chain reaction (PCR) assay. Food Control 50:9-17.

Ozpinar H, Tezmen G, Gokce I, Tekiner IH. 2013. Detection of animal species in some meat and meat products by comparatively using DNA microarray and real time PCR methods. Kafkas Univ. Vet. Fak. 19(2):245-52.

Piotrowska M. 2009. The theoretical costs of DNA barcoding. Biological Theory $4(3): 235-9$.

Potter L. 2012. A timeline of horse slaughter legislation in the United States. I-5 Publishing; 2012 [Accessed 2014 December 1, 2014] Available from: http://www.horsechannel.com/horse-resources/horse-slaughter-timeline.aspx.

Qi XB, Jianlin H, Wang G, Rege JEO, Hanotte O. 2010. Assessment of cattle genetic introgression into domestic yak populations using mitochondrial and microsatellite DNA markers. Anim. Genet. 41(3):242-52.

Ratnasingham S, Hebert PDN. 2013. A DNA-based registry for all animal species: The barcode index number (BIN) system. PLoS One 8(7).

Reisch MS. 2014. Fighting food fraud. Chemical and Engineering News. Washington, DC: ACS. p. 8-15.

Restani P, Ballabio C, Tripodi S, Fiocchi A. 2009. Meat allergy. Curr. Opin. Allergy. Cl. 9(3):265-9.

Roth AE. 2007. Repugnance as a constraint on markets. J. Econ. Perspect. 21(3):37-58.

Safdar M, Junejo Y. 2015. Development and validation of fast duplex real-time PCR assays based on SYBER Green florescence for detection of bovine and poultry origins in feedstuffs. Food Chem. 173:660-4. 
Sarpong S. 2014. Traceability and supply chain complexity: confronting the issues and concerns. European Business Review 26(3):14.

Sistani SA. 2013. Food \& drink: Permitted and prohibited. Islamic Laws: Digital Islamic Library Project.

Smiley J. 2008. Why horse slaughter is necessary. New York Times.

Spink J, Moyer DC. 2011. Defining the public health threat of food fraud. J. Food Sci. 76(9):R157-R63.

Stoeckle M. 2003. Taxonomy, DNA, and the Bar Code of Life. BioSci. 53(9):796-7.

Taylor A, Willett M. 2013. There's no good reason why America doesn't eat horses. New York, NY: Business Insider.

USDA. Game from farm to table. Washington, DC: U. S. Dep. Agric.; 2011 [Accessed 2014 December 12, 2014] Available from: http://www.fsis.usda.gov/wps/wcm/connect/e432ba38-79f6-42c8-af50$\underline{\text { df7cf788a298/Game from_Farm to Table.pdf?MOD=AJPERES. }}$.

USDA. Economic Research Service. Washington, DC: U. S. Dep. Agric.; 2014a [Accessed 2014 December 12, 2014] Available from: http://www.ers.usda.gov/data-products/meat-price-spreads.aspx.

USDA. 2014b. USDA Weekly National Lamb Market Summary. Washington, DC: U. S. Dep. Agric.

USDA. Ground Beef and Food Safety. Washington, DC: United States Department of Agriculture Food Safety and Inspection Service; 2013 [Accessed 2014 Novemeber 13] Available from: http://www.fsis.usda.gov/wps/portal/fsis/topics/food-safety-education/get- 
answers/food-safety-fact-sheets/meat-preparation/ground-beef-and-foodsafety/CT Index.

USDA. Export requirements for Mexico. Washington, DC: U.S. Dep. Agric.; 2015 [Accessed 2015 May, 8] Available from: http://www.fsis.usda.gov/wps/portal/fsis/topics/international-affairs/exportingproducts/export-library-requirements-by-country/mexico.

Yancy HF, Washington JD, Callahan L, Mason JA, Deaver CM, Farrell DE, Ha T, Sespico E, Falmlen D, Myers MJ. 2009. Development, evaluation, and peer verification of a rapid real-time PCR method for the detection of animal material. J. Food Prot. 72(11):2368-74.

Yosef TA, Al-Julaifi MZ, AL-Rizqi AM. 2014. Food Forensics: Using DNA-based technology for the detection of animal species in meat products. Nat. Sci. 12(6):82-90. 


\section{Manuscript Draft}

Identification of Species in Ground Meat Products Sold on the U.S. Commercial

\section{Market using DNA-Based Methods}

Dawn E. Kane and Rosalee S. Hellberg*

Chapman University, Schmid College of Science and Technology, Food Science and Nutrition, One University Drive, Orange, CA 92866

*Corresponding Author

Rosalee S. Hellberg, Ph.D.

Chapman University

Phone: (714) 628-2811

Fax: (714) 289-2041

E-mail: hellberg@chapman.edu 


\section{Abstract}

The objective of this study was to test a variety of ground meat products sold on

the U.S. commercial market for the presence of potential mislabeling. Forty-eight ground meat samples were purchased from online and retail sources, including both supermarkets and specialty meat retailers. DNA was extracted from each sample in duplicate and tested using DNA barcoding of the cytochrome $c$ oxidase I (COI) gene. The resulting sequences were identified at the species level using the Barcode of Life Database (BOLD). Any samples that failed DNA barcoding went through repeat extraction and sequencing, and due to the possibility of a species mixture, they were tested with realtime polymerase chain reaction (PCR) targeting beef, chicken, lamb, turkey, pork and horse. Of the 48 samples analyzed in this study, 38 were labeled correctly and 10 were found to be mislabeled. Nine of the mislabeled samples were found to contain additional meat species based on real-time PCR, and one sample was mislabeled in its entirety. Interestingly, meat samples ordered from online specialty meat distributors had a higher rate of being mislabeled (35\%) compared to samples purchased from a local butcher $(18 \%)$ and samples purchased at local supermarkets (5.8\%). Horsemeat, which is illegal to sell on the U.S. commercial market, was detected in two of the samples acquired from online specialty meat distributors. Overall, the mislabeling detected in this study appears to be due to either intentional mixing of lower-cost meat species into higher cost products or unintentional mixing of meat species due to cross-contamination during processing. 
Keywords: DNA barcoding, ground meat, species identification, mislabeling, real-time PCR

\section{Introduction}

Consumers rely on the accuracy of food labeling to help them make informed food choices for purchase, whether it be for religious purposes (some religions do not permit the consumption of pork), organic and fair trade options, or allergy concerns (Ballin, 2010). However, previous market studies in Mexico, Turkey, and South Africa have reported mislabeling rates of approximately $20-70 \%$ for a variety of meat products, including sausage, ground meat, meat balls, deli meats, and dried meats (Ayaz, Ayaz, \& Erol, 2006; Cawthorn, Steinman, \& Hoffman, 2013; D'Amato, Alechine, Cloete, Davison, \& Corach, 2013; Flores-Munguia, Bermudez-Almada, \& Vazquez-Moreno, 2000; Ozpinar, Tezmen, Gokce, \& Tekiner, 2013). For example, a South African study testing processed meat products found that $68 \%$ of the samples contained species that were not declared on the package labels (Cawthorn et al., 2013). Furthermore, in a meat adulteration scandal in Europe, undeclared horsemeat was found in products labeled as 100\% beef (British Broadcasting Corporation [BBC] News, 2013). In this survey conducted on lasagna products advertised as containing beef, the Food Standards Agency (FSA) found that $61 \%$ of products tested contained undeclared horsemeat. Similarly, a survey in Ireland testing a number of beef burgers, ground beef products, and salami for adulteration found that $37 \%$ of the products contained undeclared horsemeat and $85 \%$ of the products contained undeclared pork (Food Safety Authority of Ireland [FSAI], 2013). 
Since becoming aware of these issues, Europe has become pro-active in their testing to help prevent the sale of adulterated meat products.

In the United States, adulteration and misbranding of meat products is prohibited under the United States Code (USC) Meat Inspection Act, Title 21, Chapter 12, Subchapter I; Inspection requirements; Adulteration and Misbranding, which states that products of animals such as cattle, sheep, swine and goats that are intended for human consumption shall not be adulterated or misbranded at the time of sale, while they are being transported in commerce, or held for sale after transportation (United States Code [USC], 2011). The United States Department of Agriculture (USDA) also monitors game meats that are domestically produced for sale in the United States (The United States Department of Agriculture [USDA], 2011), while the U.S. Food and Drug Administration (FDA) regulates imported game meats according to the Federal Food Drug and Cosmetic Act (FD\&C), Chapter VIII, Section 381(m) (U.S. Food and Drug Administration [FDA], 2010). As stated in the Code of Federal Regulations (CFR) Title 9, Chapter III, Subchapter A, Part 301.2, misbranding of meat includes the use of a label that is false or misleading in any way or offering a meat product for sale under the name of another food (Code of Federal Regulations [CFR], 2014). Although there are government regulations in place, a study conducted over two decades ago in Florida, USA, reported the occurrence of meat adulteration in ground meat products, with $16.6 \%$ of the products tested found to be mislabeled (Hsieh, Woodward, \& Ho, 1995). Intact meats were also tested, but none of these products was found to be mislabeled.

The above instances of mislabeling represent cases of food fraud, which may be a result of factors such as poor traceability, accidental cross contamination resulting from 
improper handling, inadequate cleaning of equipment between species, or intentional fraud carried out for reasons such as economic gain (Cawthorn et al., 2013; Everstine, Spink, \& Kennedy, 2013; Hsieh et al., 1995; Spink \& Moyer, 2011). Assessment of proper species labeling in processed products often requires DNA or protein analysis. DNA barcoding is a molecular-based system that uses a standardized genetic region to identify biological specimens (Hebert, Ratnasingham, \& deWaard, 2003). The DNA barcode for most animal species is a $\sim 650$ base-pair $(\mathrm{bp})$ region of the mitochondrial gene coding for cytochrome $c$ oxidase subunit 1 (COI). This method has been found to be highly effective in identifying many animal species, as it shows relatively low genetic divergence within species and high divergence between species (Hebert, Cywinska, Ball, $\&$ deWaard, 2003). Furthermore, DNA barcoding has been successfully used to identify species in a variety of food products, including meat (D'Amato et al., 2013) and seafood (Hellberg \& Morrissey, 2011). Despite the advantages of DNA barcoding, it currently is not capable of identifying multiple species in the same product (Hellberg \& Morrissey, 2011). In these cases, alternative methods such as real-time polymerase chain reaction (PCR) or next-generation sequencing must be employed.

Although extensive meat species testing has been carried out in Europe in light of the 2013 horsemeat scandal, there has been limited research carried out on this topic in the United States, with the most recent U.S. meat survey having been published in 1995. Therefore, the objective of this study was to test a variety of ground meat products sold on the U.S. commercial market for the presence of potential mislabeling. In cases where samples failed to be identified with DNA barcoding, real-time PCR was used as a supplementary test due to the possibility of a species mixture. 


\section{Materials and Methods}

\subsection{Sample collection}

A total of 48 fresh/frozen ground meat products representing a variety of species were collected for use in this project (Fig.1). Products were purchased from 5 online specialty meat distributors and 4 retail outlets in Orange County, CA (3 supermarkets and 1 butcher). These samples represented 15 different meat types, including products labeled as antelope $(n=1)$, beef $(n=9)$, bison $(n=5)$, black bear $(n=1)$, duck $(n=1)$, elk $(n=3)$, emu $(n=1)$, goat $(n=1)$, kangaroo $(n=2)$, turkey $(n=7)$, veal $(n=2)$, lamb $(n=3)$, chicken $(n=4)$, pork $(n=6)$ and yak $(n=2)$. Products were packaged either as ground meat or as ground burgers/patties. Following collection, all of the products were catalogued and stored at $-80{ }^{\circ} \mathrm{C}$. Prior to sampling, products were thawed overnight at 4 ${ }^{\circ} \mathrm{C}$. For each sample, a total of $30.0 \pm 2.0 \mathrm{~g}$ was weighed into a separate, sterile $24-\mathrm{oz}$ Whirl-pak bag (Nasco, Salida, CA) and homogenized with $60.0 \mathrm{~mL}$ of sterile water in a Stomacher $^{\circledR} 400$ Circulator (Seward, Davie, FL) at $230 \mathrm{rpm}$ for 2 min (Okuma \& Hellberg, 2014). Two $\sim 10 \mathrm{mg}$ subsamples of each homogenized product were then placed into two separate $1.5 \mathrm{~mL}$ microcentrifuge tubes for DNA extraction.

\subsection{DNA extraction}

DNA extraction was carried out in duplicate for all ground meat samples using the DNeasy Blood and Tissue Kit (Qiagen, Valencia, CA), Spin-Column protocol, with modifications described in Handy, Deeds, Ivanova, Hebert, Hanner, Ormos and Yancy (2011). Following sample collection as described above, the tissue samples were lysed with $50 \mu \mathrm{L}$ Buffer ATL and 5.56 $\mu \mathrm{L}$ Proteinase $\mathrm{K}$ over a period of $1-3 \mathrm{~h}$ at $56{ }^{\circ} \mathrm{C}$ with vortexing at $30 \mathrm{~min}$ increments. Next, 55.6 $\mu \mathrm{L}$ Buffer AL and 55.6 $\mu \mathrm{L}$ 95\% ethanol were 
added to each sample tube and the tube was vortexed. The samples were then transferred to columns and centrifuged for $1 \mathrm{~min}$ at $8,000 \mathrm{rpm}$. The column membrane was washed with $140 \mu \mathrm{L}$ of AW1 buffer and centrifuged for $1 \mathrm{~min}$ at $8,000 \mathrm{rpm}$ followed by a second wash with $140 \mu \mathrm{L}$ of AW2 buffer and centrifuged for $3 \mathrm{~min}$ at 14,000 rpm. The columns were transferred to a sterile $1.5 \mathrm{~mL}$ microcentrifuge tube prior to adding $50 \mu \mathrm{L}$ of $\mathrm{AE}$ buffer preheated to $37^{\circ} \mathrm{C}$. The samples were then centrifuged for $1 \mathrm{~min}$ at $8,000 \mathrm{rpm}$ to collect the eluted DNA. A reagent blank with no tissue added was included alongside each set of extracted samples.

\subsection{PCR and sequencing}

The mammalian primer cocktails described by Ivanova, Clare and Borisenko (2012) were used to amplify a 658-bp region of the gene coding for COI. PCR was carried out as described in Ivanova et al. (2012) except that OmniMix HS (Cepheid, Sunnyvale, CA) lyophilized PCR reagent beads were used in place of adding individual reagents and the total reaction volume was increased to $25 \mu \mathrm{L}$. Each reaction included the following components: 0.5 OmniMix HS PCR bead, $22.5 \mu \mathrm{L}$ molecular grade water, $0.25 \mu \mathrm{L}$ of each $10 \mu \mathrm{M}$ primer cocktail, and $2 \mu \mathrm{L}$ of DNA. Cycling conditions were followed according to Ivanova et al. (2012): $94{ }^{\circ} \mathrm{C}$ for $2 \mathrm{~min}$; 5 cycles of $94{ }^{\circ} \mathrm{C}$ for $30 \mathrm{~s}$, $50{ }^{\circ} \mathrm{C}$ for $40 \mathrm{~s}$, and $72{ }^{\circ} \mathrm{C}$ for $1 \mathrm{~min} ; 35$ cycles of $94{ }^{\circ} \mathrm{C}$ for $30 \mathrm{~s}, 55^{\circ} \mathrm{C}$ for $40 \mathrm{~s}$, and $72{ }^{\circ} \mathrm{C}$ for $1 \mathrm{~min}$; and a final extension step at $72{ }^{\circ} \mathrm{C}$ for $10 \mathrm{~min}$. Thermocycling was carried out with a Mastercycler nexus gradient thermal cycler (Eppendorf, Hauppauge, NY). A nontemplate control (NTC) containing sterile water in place of DNA was included with each PCR run. 
Confirmation of PCR was achieved as described in Hellberg, Kawalek, Van, Shen and Williams-Hill (2014) with slight modifications. PCR products $(4 \mu \mathrm{L})$ were loaded along with sterile water $(16 \mu \mathrm{L}$ ) onto pre-cast $2.0 \%$ E-gels (Life Technologies, Carlsbad, $\mathrm{CA}$ ) and run for 6-10 min using an E-Gel iBase Power System (Life Technologies). Results were captured using Foto/Analyst Express (Fotodyne, Hartland, WI) combined with Transilluminator FBDLT-88 (Fisher Scientific, Waltham, MA) and visualized with PCIMAGE (version 5.0.0.0 Fotodyne, Hartland, WI). Amplified products were purified using ExoSAP-IT (Affymetrix, Santa Clara, CA) according to the manufacturer's instructions. The samples were then sent to GenScript (Piscataway, NJ) for bi-directional sequencing using BigDye Terminator v3.1 Cycle Sequencing Kit (Life Technologies) and a 3730xl Genetic Analyzer (Life Technologies).

\subsection{Sequence analysis}

Raw sequence files were assembled and edited using Geneious R7 (Biomatters Ltd., Auckland, New Zealand). The resulting consensus sequences were then aligned using ClustalW and trimmed to the 658-bp COI DNA barcode region. The consensus sequence lengths, \% high quality bases (HQ\%), and number of ambiguities were recorded. Samples were considered to have been successfully sequenced if they met the following requirements outlined in Handy et al. (2011): bidirectional sequences $\geq 500 \mathrm{bp}$ in length with $<2 \%$ ambiguities or a single-read $\geq 500$ bp in length with $\geq 98 \% \mathrm{HQ}$. Consensus sequences were queried against the Barcode of Life Database (BOLD) species identification tool (http://www.boldsystems.org/) using the Species Level Barcode Records option, to determine the top species match. If a species was unable to be identified using BOLD, a search was conducted in GenBank using the Basic Local 
Alignment Search Tool (BLAST). The top species matches in GenBank, along with Query Coverage (\%) and \% Identity were recorded. Preferred common names for the identified species were determined using the Encyclopedia of Life [(EOL) (http://eol.org/)]. Any samples that failed sequencing or were initially identified as mislabeled underwent repeat DNA extraction, PCR, and sequencing. Samples that initially failed sequencing were also tested with real-time PCR, as described below, due to the possibility of a species mixture.

\subsection{Real-time PCR}

Real-time PCR was used to test for the presence of commonly found species in ground meats (i.e., beef, lamb, chicken, turkey, and pork) as well as horse, as described in Okuma and Hellberg (2014). Amplification was carried out using a Rotor-Gene ${ }^{\circledR} \mathrm{Q}$ Cycler (Qiagen, Germantown, MD) and each reaction tube included $12.5 \mu \mathrm{L} \mathrm{iQ}^{\mathrm{TM}}$ SYBR $^{\circledR}$ Green Supermix (2X) (Bio-Rad, Hercules, CA), 8.5 $\mu \mathrm{L}$ molecular grade water, $1.0 \mu \mathrm{L}$ of each oligonucleotide forward and reverse primer, and 2.0 $\mu \mathrm{L}$ DNA. The final primer concentrations were $0.16 \mu \mathrm{M}$ for beef, $0.25 \mu \mathrm{M}$ for lamb, $0.2 \mu \mathrm{M}$ for chicken and turkey, and $0.3 \mu \mathrm{M}$ for pork and horse. Positive DNA controls for each meat species were prepared in three 10 -fold serial dilutions $\left(10^{-1}, 10^{-2}\right.$ and $\left.10^{-3}\right)$ using Tris-EDTA buffer, pH 8.0 (BioExpress, Kaysville, UT) and were included in each PCR run. An NTC containing sterile water in place of DNA was also run along with every set of samples. PCR cycling conditions for identification of beef, lamb, chicken, and turkey were: $94{ }^{\circ} \mathrm{C}$ for $2 \mathrm{~min}$, followed by 50 cycles of $94{ }^{\circ} \mathrm{C}$ for $10 \mathrm{~s}, 58.9^{\circ} \mathrm{C}$ for $15 \mathrm{~s}$, and $72{ }^{\circ} \mathrm{C}$ for $40 \mathrm{~s}$. Pork and horse settings were: $94{ }^{\circ} \mathrm{C}$ for $2 \mathrm{~min} ; 35$ cycles of $94{ }^{\circ} \mathrm{C}$ for $50 \mathrm{~s}, 55^{\circ} \mathrm{C}$ for $50 \mathrm{~s}$, and $72{ }^{\circ} \mathrm{C}$ for $1 \mathrm{~min}$; then $72{ }^{\circ} \mathrm{C}$ for $5 \mathrm{~min}$. Melt curve analysis was completed at the end 
of each run. Results were determined to be positive if at least one of the subsamples tested had a $\mathrm{Ct}$ value for the meat species being tested and had a melting temperature within $0.5^{\circ} \mathrm{C}$ of the average positive control melting temperatures for that run (Okuma \& Hellberg, 2014). Results were qualitative and reported as presence or absence of the target species.

\section{Results and Discussion}

\subsection{DNA barcoding results}

Of the 48 samples collected in this study, 39 samples were successfully bidirectionally sequenced to assemble a COI barcode for both replicates prepared during DNA extraction (Table 1). The average sequence length for these samples was $651 \pm 19$ bp, the average ambiguity was $0.14 \pm 0.54 \%$ and the average HQ\% was $87.5 \pm 12.0 \%$. A total of 9 samples showed sequencing failure in one or both replicates. These samples underwent repeat DNA extraction and sequencing, as well as testing with real-time PCR in case of a species mixture. This follow-up testing resulted in successful sequencing for

two replicates in 7 of the samples and successful sequencing for only one replicate in 2 of the samples. Based on the combination of sequencing and real-time PCR results, all 9 samples were found to contain multiple species. These samples are discussed in detail in the following section.

Among the 39 samples found to contain just one species, sequence queries against BOLD allowed for positive identification at the species level for 38 of the samples with pairwise similarities of $\geq 99.7 \%$ (Table 1). One of the samples labeled as kangaroo burgers could not be identified using BOLD and was instead queried against GenBank, which resulted in a $100 \%$ genetic match to Western grey kangaroo (Macropus 
fuliginosus). All of these samples were found to be correctly labeled except one product purchased from an online specialty meat distributor which was labeled as yak burgers but identified as cattle (Bos taurus)/zebu cattle (Bos indicus). This identification was confirmed following repeat DNA extraction and sequencing. This distributor sells ground beef products for US $\$ 22.00 / \mathrm{kg}$ compared to their yak burgers which retail for US $\$ 43.98 / \mathrm{kg}$. This is a case where economic gain is a likely cause of mislabeling, as substituting the lower-cost beef for yak can result in a two-fold profit for the company. Among the correctly labeled samples, 13 were purchased from online specialty meat distributors, 9 were purchased from a local butcher, and 16 were purchased from local supermarkets.

\subsection{Mixed-species samples}

As mentioned above, 9 of the samples tested in this study were found to contain multiple species (Table 2). These samples were tested with both DNA barcoding and real-time PCR, and consisted of products labeled as turkey $(\mathrm{n}=3)$, lamb $(\mathrm{n}=1)$, black bear $(n=1)$, chicken $(n=1)$, bison $(n=1)$, kangaroo $(n=1)$ and yak $(n=1)$. Two of the three samples labeled as ground turkey (K21 and K23) were purchased from a local butcher and one sample labeled as turkey burgers (K34) was purchased from an online specialty meat distributor. All three samples listed USA as country of origin. Results from DNA barcoding indicated a species identity match of $100 \%$ to wild turkey (Meleagris gallopavo) for the successful sequencing replicates originating from the two samples from the local butcher, while the sample from the online specialty meat distributor had one sequencing replicate with a $100 \%$ match to wild turkey and another replicate with a $100 \%$ match to chicken/red junglefowl (Gallus gallus). Additional 
testing with real-time PCR revealed multiple undeclared species in these products. In addition to confirming the presence of turkey in all three products, real-time PCR results for the turkey samples from the local butcher (K21 and K23) revealed the presence of lamb, chicken, and beef, while the sample from the online specialty meat distributor (K34) was positive for lamb and chicken. The undeclared species that were detected in the turkey samples with real-time PCR were either more expensive than turkey (beef and lamb) or considered about the same relative cost (chicken) as turkey, indicating that economic fraud was not the cause of mislabeling (USDA, 2014a, 2014b). Both the local butcher and the online specialty meat distributor sell several varieties of ground meats, including beef, chicken and lamb. The presence of multiple species commonly found in ground meats, and the fact that these retailers sell the species detected suggests the possibility of cross-contamination at the processing facility. Unintentional mislabeling may occur when several species are ground on the same manufacturing equipment, without proper cleaning in between samples (Hsieh et al., 1995).

The product labeled as ground chicken (K27) that was found to contain multiple species was purchased from a local supermarket and listed USA as the country of origin. This sample was identified as chicken in BOLD with a $100 \%$ species identity match. However, real-time PCR indicated the presence of beef, turkey and lamb in addition to chicken. Because the cost of the undeclared species is typically higher than or similar to the cost of chicken (USDA, 2014a, 2014b), economic gain is not suspected here and, similar to the mislabeled turkey products discussed above, the mislabeling is more likely due to cross-contamination at the processing facility. Importantly, the presence of mammalian species in products labeled as only containing poultry is concerning for 
individuals that are intentionally avoiding these species due to a meat allergy (Restani, Ballabio, Tripodi, \& Fiocchi, 2009). While meat allergies are uncommon, they can have serious health consequences, such as hives, asthma or even anaphylactic shock (Restani et al., 2009).

The sample labeled as yak burgers (K31) that was found to contain multiple species was purchased from an online specialty meat distributor and listed USA as the country of origin. The sequencing results for this sample initially showed a top species match to cattle with $100 \%$ genetic similarity; however, following repeat DNA extraction and sequencing, the top species match was to guanaco (Lama guanicoe) with 100\% similarity, with secondary species matches of $99.2-99.4 \%$ to llama (Lama glama) and alpaca (Lama pacos). Guanaco, llama, and alpaca likely cannot be differentiated using the COI barcode region due to a history of interbreeding and domestication (Barreta et al., 2013). Real-time PCR results confirmed the presence of beef in the sample, with no additional species detected. The use of guanaco/llama/alpaca does not represent a case of economic gain, as the cost of ground llama and ground alpaca sold from this online specialty meat distributor (US $\$ 21.89 / \mathrm{kg}$ ) is greater than the cost of ground yak (US $\$ 19.69 / \mathrm{kg}$ ) sold by the same distributor. However, the use of beef in the product would be an instance of economic fraud, as the average price per kilogram for ground beef (US $\$ 9.14 / \mathrm{kg}$ ) (USDA, 2014a) is about half that of ground yak.

The mixed-species sample labeled as black bear burgers (K30) was purchased from an online specialty meat distributor and listed USA as the country of origin. Sequencing results identified the sample as American beaver (Castor canadensis) with a $100 \%$ species match. Additional testing with real-time PCR on this product revealed the 
presence of pork in the sample as well. Interestingly, black bear burgers were previously implicated in a case of labeling fraud uncovered by the FDA (FDA, 2011). In 2011, the FDA issued a warning letter to an online specialty meat distributor on multiple accounts of food fraud stating that the black bear (Ursus americanus) burgers being sold were found to contain elk/red deer (Cervus sp.) and that products labeled as black bear steaks were, in actuality, brown bear (Ursus arctos). Similarly, the black bear burgers tested in the current study were not labeled properly and represent a case of food fraud. Since the cost of ground beaver offered by the same online specialty meat distributor was equivalent to the cost of ground black bear, this may represent a case of substitution due to mishandling or supply shortages. Alternatively, the presence of pork in the product does indicate economic fraud by mixing in a lower-cost meat. This online specialty meat distributor sells both black bear burgers and ground beaver meat for US $\$ 21.89 / \mathrm{kg}$, whereas the average cost of pork is listed at US $\$ 9.13 / \mathrm{kg}$ (USDA, 2014a), suggesting that substitution for economic gain is a viable explanation.

The mixed-species sample labeled as ground kangaroo (K38) was also obtained through an online specialty meat distributor and listed a country of origin of Australia. This sample could not be identified at the species level in BOLD, but showed a top match to Western grey kangaroo when searched in GenBank, with a genetic similarity of $96 \%$. Real-time PCR results also indicated the presence of beef in the sample. The mixing of beef with kangaroo meat could be economically motivated or could be due to crosscontamination during processing. This online specialty meat distributor sells ground kangaroo for US $\$ 19.76 / \mathrm{kg}$ compared with ground beef at US $\$ 9.90 / \mathrm{kg}$, resulting in a 
potential profit to be made by mixing in the lower-cost beef with the more expensive kangaroo meat.

Two of the samples with multiple species detected were found to contain horsemeat (Table 2). These samples were labeled as ground bison (K35) and ground lamb meat (K29) and were purchased from two different online specialty meat distributors. The sample labeled as ground bison had a top match in BOLD to American elk (Cervus canadensis) with 97.8\% genetic similarity, and real-time PCR also revealed the presence of beef, pork, and horse. The sample labeled as ground lamb was identified as lamb/sheep (Ovis aries) in BOLD with 100\% genetic similarity and real-time PCR revealed the presence of pork and horse in addition to lamb. The sample labeled as lamb listed the USA as its country of origin, whereas the sample labeled as bison listed Canada as its country of origin. In addition to being mislabeled, these two samples are also in violation of U.S. regulations against the sale of horsemeat. In 2007, nine years after U.S. voters first passed Proposition 6, which banned the slaughter of horses and similar equines for sale for their meat for human consumption, Congress passed the American Horse Slaughter Prevention Act, prohibiting the sale of equines including horses and mules for human consumption under the Federal Meat Inspection Act (FMIA) (Library of Congress, 2011; Potter, 2012). This includes the prohibition of shipping, transporting, moving, delivering, receiving, possessing, purchasing, selling or donation of horses and other equines for human consumption (Library of Congress, 2011). Along with a nationwide ban on selling horsemeat for human consumption, some states (including California) have a law of repugnance which prevents selling any part of a horse for human consumption (California Penal Code [CPC], 1998; Roth, 2007). 
Overall, mislabeling was found to be most common in products purchased from online specialty meat distributors, which showed a $35 \%$ rate of mislabeling and included products labeled as black bear and yak burgers. The next-highest rate of mislabeling (18\%) was found in samples purchased from a local butcher, for which two samples labeled as ground turkey were identified as mislabeled. Local supermarkets showed the lowest rate of mislabeling (5.8\%), with just one product labeled as ground chicken found to be mislabeled.

\subsection{Comparison to previous studies}

The rate of mislabeling found in the current study of $21 \%$ is slightly higher than that found by a previous U.S. study, which reported a mislabeling rate of $16.6 \%$ for ground meats (Hsieh et al., 1995). A possible reason for the difference in these rates is that Hsieh et al. (1995) did not examine game meats, which showed a higher rate of mislabeling in the current study (27.8\%) compared to the mislabeling rate for non-game meats $(16.7 \%)$. Interestingly, the previous study reported that products labeled as ground beef and veal were most likely to be mislabeled or contain undeclared species, whereas in the current study, none of the products labeled as beef or veal were found to be mislabeled. However, in both studies beef was found to be a commonly undeclared species detected in products. In this study, of the 9 mislabeled samples containing mixed species, 6 were found to contain beef. Besides beef, common undeclared species found in both studies were lamb, poultry and pork. Similar to the current study, previous studies have also reported the presence of horse as an undeclared ingredient (Ayaz et al., 2006; Flores-Munguia et al., 2000). For example, a study conducted in Mexico reported horse in $39 \%$ of hamburger samples labeled as containing 100\% beef (Flores-Munguia et 
al., 2000). The authors noted that in Mexico, horse is of lower quality and value than beef and it is regulated less than other meat species, providing the potential for it to be mixed into higher-priced ground meats. Studies conducted in South Africa have also reported widespread mislabeling of ground meats, with products containing undeclared pork and lamb, as well as high rates of mislabeling of game meats (D'Amato et al., 2013). Similar to the current study, previous instances of mislabeling have been attributed to factors such as economic incentive, human error, improper identification and labeling of game meat species, and insufficient cleaning techniques of equipment that multiple species are ground on.

\section{Conclusions}

The overall results of this study indicate the presence of mislabeling in ground meat products sold on the U.S. commercial market. The majority of mislabeled products, including two samples found to contain horsemeat, were acquired from online specialty meat distributors, with only one mislabeled sample acquired from a supermarket. Despite government regulations in place to prevent misbranding of food products, it is apparent that some ground meat products are mislabeled and, in some cases, contain multiple species. The overall trends for mislabeling found in this study indicate the possibility of lower-cost species being intentionally mixed in with higher-cost species for economic gain as well as unintentional mixing of multiple species due to cross-contamination in the processing facility. The results of this study indicate the importance of continuous monitoring of commercial ground meat products for mislabeling, especially in the case of online specialty meat distributors.

\section{Acknowledgements}


The authors would like to thank Chapman University Schmid College of Science and

Technology, the Office of the Chancellor and the Graduate Academic Council for grant

support. None of these entities were involved with the design or execution of the study.

\section{References}

Ayaz, Y., Ayaz, N. D., \& Erol, I. (2006). Detection of species in meat and meat products using enzyme-linked immunosorbent assay. J. Muscle Foods, 17(2), 214-220. http://dx.doi.org/10.1111/j.1745-4573.2006.00046.x

Ballin, N. Z. (2010). Authentication of meat and meat products. Meat Sci., 86(3), 577587. http://dx.doi.org/10.1016/j.meatsci.2010.06.001

Barreta, J., Gutierrez-Gil, B., Iniguez, V., Saavedra, V., Chiri, R., Latorre, E., et al., (2013). Analysis of mitochondrial DNA in Bolivian llama, alpaca and vicuna populations: A contribution to the phylogeny of the South American camelids. Anim. Genet., 44(2), 158-168. http://dx.doi.org/10.1111/j.13652052.2012.02376.x

BBC News. (2013). Findus beef lasagne contains up to $100 \%$ horsemeat, FSA says. $B B C$ News UK. Accessible at http://www.bbc.co.uk/news/uk-21375594 Accessed 11.12 .14

Cawthorn, D.-M., Steinman, H. A., \& Hoffman, L. C. (2013). A high incidence of species substitution and mislabelling detected in meat products sold in South Africa. Food Control, 32(2), 440-449. http://dx.doi.org/10.1016/j.foodcont.2013.01.008

CFR. (2014). Code of Federal Regulations. Washington, DC: U.S. Gov. Print. Off. Accessible at http://www.gpo.gov/fdsys/browse/collectionCfr.action?collectionCode=CFR\&sea $\underline{\text { rchPath}=\text { Title }+9 \% 2 F C h a p t e r+I I I \% 2 F S u b c h a p t e r ~}+\mathrm{A} \% 2 \mathrm{FPart}+301 \&$ oldPath=Title $+9 \% 2 \mathrm{FChapter}+\mathrm{III} \% 2 \mathrm{FSubchapter}+\mathrm{A} \% 2 \mathrm{FPart}+303 \&$ isCollapsed=true\&selected YearFrom $=2014 \&$ ycord $=360$. Accessed 09.12.14

CPC. (1998, 2012). California Penal Code 598. Accessible at http://www.leginfo.ca.gov/cgi-bin/displaycode? section=pen \&group $=00001$ 01000\&file=594-625c Accessed 08.11.14

D'Amato, M. E., Alechine, E., Cloete, K. W., Davison, S., \& Corach, D. (2013). Where is the game? Wild meat products authentication in South Africa: A case study. Invest. Genet., 4(1). http://dx.doi.org/10.1186/2041-2223-4-6

Everstine, K., Spink, J., \& Kennedy, S. (2013). Economically motivated adulteration (EMA) of food: Common characteristics of EMA incidents. J. Food Prot., 76(4), 723-735. http://dx.doi.org/10.4315/0362-028x.jfp-12-399

FDA. (2010). Federal Food, Drug, and Cosmetic Act (FD\&C Act). 2006. Accessible at http://www.fda.gov/RegulatoryInformation/Legislation/FederalFoodDrugandCos meticActFDCAct/default.htm Accessed 20.12.14

FDA. (2011). U.S. Food and Drug Administration: Warning letter 2/4/11. Chicago, IL: U.S. Food and Drug Administration Accessible at http://www.fda.gov/ICECI/EnforcementActions/WarningLetters/2011/ucm24289 0.htm. Accessed 24.12.14 
Flores-Munguia, M. E., Bermudez-Almada, M. C., \& Vazquez-Moreno, L. (2000). A research note: Detection of adulteration in processed traditional meat products. $J$. Muscle Foods, 11(4), 319-325. http://dx.doi.org/10.1111/j.17454573.2000.tb00435.x

FSAI. (2013). FSAI survey finds horse DNA in some beef burger products. Food Safety Authority of Ireland. Accessible at http://www.fsai.ie/news centre/press releases/horseDNA15012013.html Accessed 12.12.14

Handy, S. M., Deeds, J., R., Ivanova, N. V., Hebert, P. D. N., Hanner, R., Ormos, A., Yancy, H. F. (2011). Single laboratory validated method for DNA-barcoding for the species identification of fish for FDA regulatory compliance (Vol. 2014). Silver Spring, MD: U.S. Food and Drug Administration.

Hebert, P. D. N., Cywinska, A., Ball, S. L., \& deWaard, J. R. (2003). Biological identifications through DNA barcodes. P. Roy. Soc. B-Biol. Sci., 270(1512), 313321. http://dx.doi.org/10.1098/rspb.2002.2218

Hebert, P. D. N., Ratnasingham, S., \& deWaard, J. R. (2003). Barcoding animal life: Cytochrome c oxidase subunit 1 divergences among closely related species. $P$. Roy. Soc. B-Biol. Sci., 270, S96-S99. http://dx.doi.org/10.1098/rsbl.2003.0025

Hellberg, R. S., Kawalek, M. D., Van, K. T., Shen, Y., \& Williams-Hill, D. M. (2014). Comparison of DNA extraction and PCR setup methods for use in highthroughput DNA barcoding of fish species. Food Anal. Method, 7(10). http://dx.doi.org/10.1007/s12161-014-9865-z

Hellberg, R. S. R., \& Morrissey, M. T. (2011). Advances in DNA-based techniques for the detection of seafood species substitution on the commercial market. JALA, 16(4), 308-321. http://dx.doi.org/10.1016/j.jala.2010.07.004

Hsieh, Y.-H. P., Woodward, B. B., \& Ho, S.-H. (1995). Detection of species substitution in raw and cooked meats using immunoassays. J. Food Prot., 58(5), 555-559.

Ivanova, N. V., Clare, E. L., \& Borisenko, A. V. (2012). DNA barcoding in mammals. Methods Mol. Biol., 858, 153-182. http://dx.doi.org/10.1007/978-1-61779-591$\underline{68}$

Library of Congress. (2011). American Horse Slaughter Prevention Act. H.R.2966, H.R.857. Accessible at http://www.congress.gov/bill/112th-congress/housebill/2966 Accessed 18.12.14

Okuma, T. A., \& Hellberg, R. S. (2014). Identification of meat species in pet foods using a real-time polymerase chain reaction (PCR) assay. Food Control, 50, 9-17. http://dx.doi.org/10.1016/j.foodcont.2014.08.017

Ozpinar, H., Tezmen, G., Gokce, I., \& Tekiner, I. H. (2013). Detection of animal species in some meat and meat products by comparatively using DNA microarray and real time PCR methods. Kafkas Univ. Vet. Fak., 19(2), 245-252. http://dx.doi.org/10.9775/kvfd.2012.7616

Potter, L. (2012). A timeline of horse slaughter legislation in the United States. Accessible at http://www.horsechannel.com/horse-resources/horse-slaughtertimeline.aspx Accessed 01.12.14

Restani, P., Ballabio, C., Tripodi, S., \& Fiocchi, A. (2009). Meat allergy. Curr. Opin. Allergy. Cl., 9(3), 265-269. http://dx.doi.org/10.1097/ACI.0b013e32832aef3d 
Roth, A. E. (2007). Repugnance as a constraint on markets. J. Econ. Perspect., 21(3), 3758. http://dx.doi.org/10.1257/jep.21.3.37

Spink, J., \& Moyer, D. C. (2011). Defining the public health threat of food fraud. J. Food Sci., 76(9), R157-R163. http://dx.doi.org/10.1111/j.1750-3841.2011.02417.x

USC. (2011). United States Code. Title 21. Chapter 12. Subchapter IV sec 676(a). Accessible at http://www.gpo.gov/fdsys/granule/USCODE-2010title21/USCODE-2010-title21-chap12-subchapIV-sec676 Accessed 13.11.14

USDA. (2011). Game from farm to table. Food Safety Information. Accessible at http://www.fsis.usda.gov/wps/wcm/connect/e432ba38-79f6-42c8-af50df7cf788a298/Game from_Farm to Table.pdf?MOD=AJPERES Accessed 12.12 .14

USDA. (2014a). Economic Research Service. Accessible at http://www.ers.usda.gov/data-products/meat-price-spreads.aspx Accessed $\underline{12.12 .14}$

USDA. (2014b). USDA Weekly National Lamb Market Summary (Vol. 21). Washington, DC: U. S. Dep. Agric. Accessible at http://www.ams.usda.gov/mnreports/lswlamb.pdf Accessed 18.12.14

Figure caption

Figure 1: Summary of meat types purchased for this study, separated by retail source 
Table 1: DNA barcoding results for samples found to contain one species. Species were identified using the Barcode of Life Database (BOLD), except where otherwise noted.

\begin{tabular}{|c|c|c|c|}
\hline Product label & Samples (n) & $\begin{array}{c}\text { Genetic } \\
\text { similarity }\end{array}$ & Top species match \\
\hline Antelope & 1 & $99.7 \%$ & Nilgai (Boselaphus tragocamelus) \\
\hline Beef & 9 & $100.0 \%$ & Cattle (Bos taurus) \\
\hline Bison/Buffalo & 4 & $99.9-100.0 \%$ & American bison (Bison bison) \\
\hline Chicken & 3 & $99.8-100.0 \%$ & $\begin{array}{l}\text { Chicken/Red junglefowl (Gallus } \\
\text { gallus) }\end{array}$ \\
\hline Duck & 1 & $100.0 \%$ & Mallard (Anas platyrhynchos) \\
\hline Elk & 3 & $99.8-100.0 \%$ & Red deer (Cervus elaphus) \\
\hline Emu & 1 & $99.8 \%$ & Emu (Dromaius novaehollandiae) \\
\hline Goat & 1 & $100.0 \%$ & Domestic goat (Capra hircus) \\
\hline Kangaroo & 1 & $100.0 \%^{a}$ & $\begin{array}{l}\text { Western grey kangaroo (Macropus } \\
\text { fuliginosus) }\end{array}$ \\
\hline Lamb & 2 & $100.0 \%$ & $\begin{array}{l}\text { Domestic sheep (Ovis aries)/mouflon } \\
\text { (O. aries musimon) }\end{array}$ \\
\hline Pork & 3 & $99.8-100.0 \%$ & Wild boar (Sus scrofa) ${ }^{b}$ \\
\hline Turkey & 4 & $99.9-100.0 \%$ & Wild turkey (Meleagris gallopavo) \\
\hline Veal & 2 & $100.0 \%$ & Cattle (B. taurus) \\
\hline Wild boar & 3 & $99.8-100.0 \%$ & Wild boar (S. scrofa) \\
\hline Yak $^{c}$ & 1 & $99.9-100.0 \%$ & $\begin{array}{l}\text { Cattle (B. taurus)/Zebu cattle (Bos } \\
\text { indicus) }\end{array}$ \\
\hline
\end{tabular}

${ }^{a}$ The sample sequences were not available in BOLD and were instead identified using BLAST. The \% identity from GenBank is given

${ }^{b}$ Domestic pig (Sus scrofa domesticus) is a subspecies of wild boar

${ }^{c}$ Sample identified as mislabeled. 
Table 2: Combination of DNA barcoding and real-time PCR results for samples found to contain multiple species.

\begin{tabular}{|c|c|c|c|c|c|c|c|c|c|}
\hline \multirow{2}{*}{$\begin{array}{l}\text { Sample } \\
\text { number }\end{array}$} & \multirow{2}{*}{$\begin{array}{l}\text { Product } \\
\text { label }\end{array}$} & \multirow{2}{*}{$\begin{array}{l}\text { Top species match with } \\
\text { DNA barcoding }\end{array}$} & \multirow{2}{*}{$\begin{array}{l}\text { Genetic } \\
\text { similarity }\end{array}$} & \multicolumn{6}{|c|}{ Real-time PCR results } \\
\hline & & & & Beef & Pork & Turkey & Sheep/Lamb & Chicken & Horse \\
\hline K30 & $\begin{array}{l}\text { Black } \\
\text { bear }\end{array}$ & $\begin{array}{l}\text { American beaver } \\
\text { (Castor canadensis) }\end{array}$ & $100.0 \%$ & - & + & - & - & - & - \\
\hline K35 & Bison & $\begin{array}{l}\text { American elk (Cervus } \\
\text { canadensis) }\end{array}$ & $97.8 \%$ & + & + & - & - & - & + \\
\hline $\mathrm{K} 27$ & Chicken & $\begin{array}{l}\text { Chicken/Red junglefowl } \\
\text { (Gallus gallus) }\end{array}$ & $100.0 \%$ & + & - & + & + & + & - \\
\hline K38 & Kangaroo & $\begin{array}{l}\text { Western grey kangaroo } \\
\text { (Macropus fuliginosus) }\end{array}$ & $96 \%$ & + & - & - & - & - & - \\
\hline K29 & Lamb & $\begin{array}{l}\text { Domestic sheep (Ovis } \\
\text { aries)/Mouflon (O. aries } \\
\text { musimon) }\end{array}$ & $100.0 \%$ & - & + & - & + & - & + \\
\hline K21 & Turkey & $\begin{array}{l}\text { Wild turkey (Meleagris } \\
\text { gallopavo) }\end{array}$ & $100.0 \%$ & + & - & + & + & + & - \\
\hline $\mathrm{K} 23$ & Turkey & $\begin{array}{l}\text { Wild turkey } \\
\text { (M.gallopavo) }\end{array}$ & $100.0 \%$ & + & - & + & + & + & - \\
\hline K34 & Turkey & $\begin{array}{l}\text { Wild turkey } \\
\text { (M.gallopavo); Chicken } \\
\text { (G. gallus) }\end{array}$ & $\begin{array}{l}100.0 \% \\
100.0 \%\end{array}$ & - & - & + & + & + & - \\
\hline K31 & Yak & $\begin{array}{l}\text { Guanaco (Lama } \\
\text { guanicoe); Cattle (Bos } \\
\text { taurus) }\end{array}$ & $\begin{array}{l}100.0 \% \\
100.0 \%\end{array}$ & + & - & - & - & - & - \\
\hline
\end{tabular}




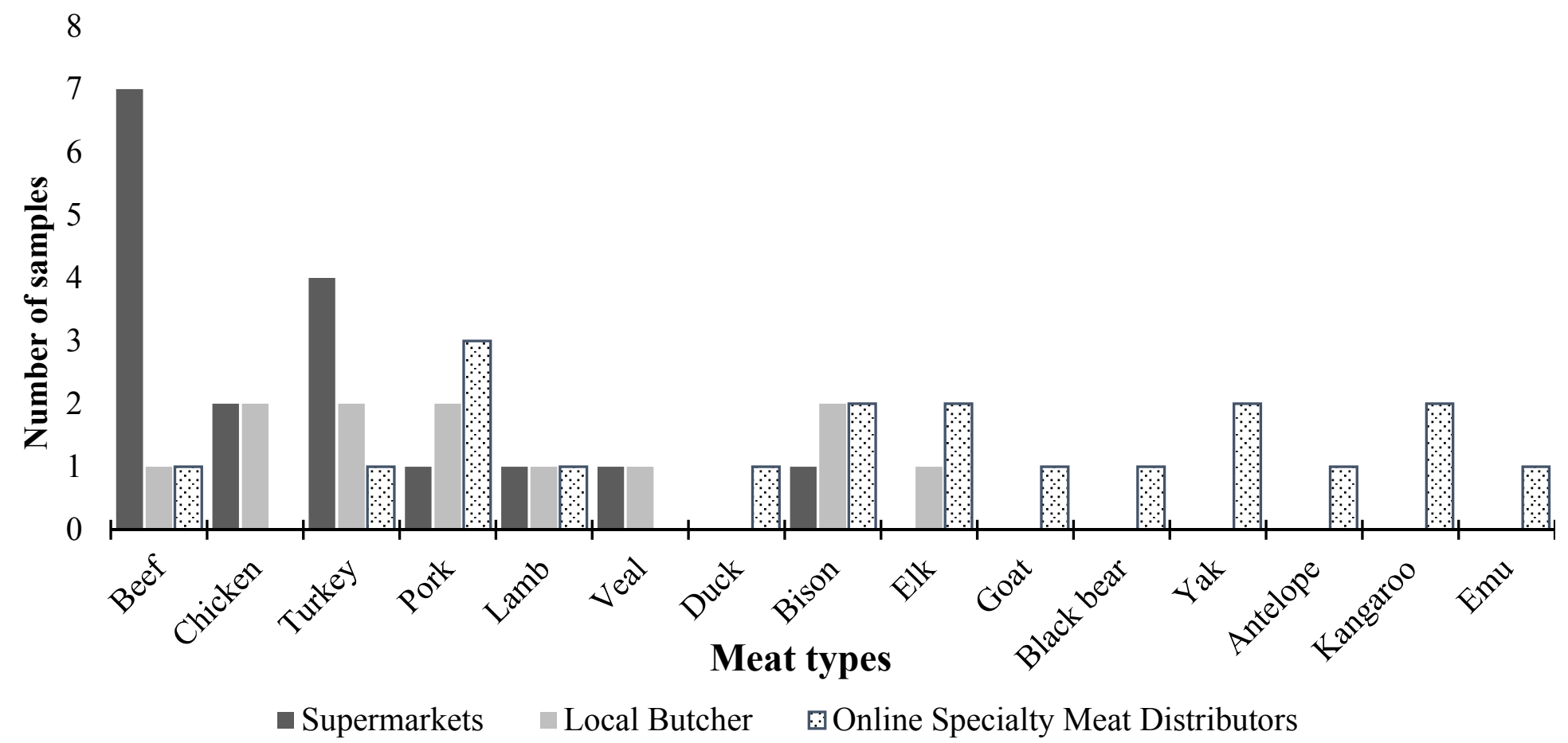

